\title{
Effects of Experimental Throughfall Exclusion on Soil Respiration in a Continental Coniferous Stand, South Korea
}

\author{
Ikhyun Kim ${ }^{1}$, Hee Mun Chae ${ }^{2, *}$ and Byoungkoo Choi ${ }^{2, *}$ \\ 1 Department of Forestry and Environmental Systems, Kangwon National University, \\ Chuncheon 24341, Korea; kih9281@kangwon.ac.kr \\ 2 Department of Forest Environment Protection, Kangwon National University, Chuncheon 24341, Korea \\ * Correspondence: cheemun@kangwon.ac.kr (H.M.C.); bkchoi@kangwon.ac.kr (B.C.); \\ Tel.: +82-33-250-8367 (H.M.C.); +82-33-250-8368 (B.C.)
}

Received: 6 August 2020; Accepted: 7 September 2020; Published: 8 September 2020

\begin{abstract}
Severe droughts and changing precipitation patterns could alter the biogeochemical properties of the soil, affecting soil carbon cycles in forest ecosystems. A throughfall exclusion (TFE) experiment was conducted in a continental climate coniferous stand in Gangwon Province, Korea, to examine the effects of excluding rainfall on total soil respiration (SR), heterotrophic soil respiration (HR), autotrophic soil respiration (AR), sapling diameter growth, and soil bacterial communities from July 2016 to October 2017. The soil water content (SWC) was significantly decreased by the exclusion of the throughfall, resulting in changes in the bacterial communities, and subsequently a decrease in HR. Although AR did not present significant differences between the control and TFE plots, the rate of sapling growth was significantly lower in the TFE plots compared with that in the control plots. An exponential function relating SR to soil temperature accounted for $0.61 \%$ and $0.82 \%$ of the variance in SR in the control and TFE plots, respectively $\left(\mathrm{Q}_{10}=2.48\right.$ and 2.86, respectively). Furthermore, a multivariate nonlinear model based on soil temperature and SWC explained $0.89 \%$ and $0.88 \%$ of the variance in SR in the control and TFE plots, respectively. When soil temperature was high, SR showed high fluctuations due to SWC variation. However, when SWC was low, we detected relatively small fluctuations in SR due to soil temperature. The results of this study show that the activity of soil microbial and root respiration during the growing season may be lower under future drought conditions.
\end{abstract}

Keywords: forest soil; throughfall exclusion; soil $\mathrm{CO}_{2}$ efflux; heterotrophic soil respiration; autotrophic soil respiration; soil bacterial community; Korean pine

\section{Introduction}

Cumulative greenhouse gas emissions, particularly those of carbon dioxide, lead to climate change effects that manifest in multiple forms, such as global warming and drought [1]. Total soil respiration (SR) is the second-largest contributor to the global carbon flux [2]. Therefore, even subtle changes in SR may affect global carbon dynamics. Soil temperature (ST) and soil water content (SWC) are important environmental determinants of SR [3-5]. To understand the impact of climate change on forest ecosystems, it is important to generate accurate estimates of the carbon dynamics in these systems, given that changes in ST and SWC impact on forest carbon cycles, while causing structural alterations in the forest $[1,6]$. $Q_{10}$ values (temperature sensitivity) are the most widely used indices for assessing the responses of soil respiration to temperature [7], and the global median value of $Q_{10}$ has been reported to be 2.4 [8]. However, with respect to forest ecosystems, $\mathrm{Q}_{10}$ values can vary considerably, depending on forest type and age, climate, and season $[7,9,10]$. 
Although the impact of severe droughts is expected to increase in both intensity and frequency during the 21st century [1], the resulting effects on SR remain unclear. Some previous studies have shown that global warming may increase SR [11,12], while others have shown that the response of SR in throughfall exclusion (TFE) experiments is highly variable, and under the control of soil moisture conditions [13-17]. Furthermore, the response of SR to TFE may depend on whether or not the evaluation is carried out during the growing season [18,19].

Carbon dioxide associated with SR is comprised of heterotrophic soil respiration (HR), produced from decomposition of organic matter by soil microorganisms, and autotrophic soil respiration (AR), from respiration of belowground plant roots [8]. AR contributes 10 to $90 \%$ to SR depending on the season in the forest ecosystems [20], and HR contributes on 45\% to SR in young coniferous stands in temperate climate [21]. SR and its components are indirectly affected by soil moisture, which affects the diffusion of oxygen through the substrate $[15,16]$. Continuous exhaustion of substrate and decreasing $\mathrm{C}$ input into the rhizosphere, which are caused by soil warming and throughfall reduction, can have negative effects on soil microbes [22]. In addition, soil temperature and moisture may also directly influence SR through changes in microbial community structures and the physiology of the vegetation present $[23,24]$. Increasing of soil temperature likely interacts with soil moisture conditions to affect soil microbes [25]. In non-limiting soil moisture conditions, soil microbial activity stimulated by increasing temperature may enhance the SR, whereas SR is reduced in response to increasing temperature under drought conditions [26,27]. Furthermore, other factors such as litter quality and the internal $\mathrm{C}$ allocation of plants, can have an effect on SR processes and its seasonal variation [28,29]. Therefore, it is difficult to predict the response of SR to changes in soil water availability [9]. In recent studies, various TFE scales have been manipulated to investigate greenhouse gases in forest ecosystems [30], and these studies have found that drought conditions change the dynamics of both HR and AR $[9,23,24,31,32]$. However, it is unclear whether HR or AR is more sensitive to drought conditions [24].

The response of the global carbon cycle and terrestrial carbon sinks to climate change varies according to temperature, $\mathrm{CO}_{2}$ concentration, and nitrogen deposition, which in turn depend on the regional climate and environmental conditions and the types of vegetation present [8,33-38]. Therefore, studies of changes in soil respiration under drought conditions in various regions is necessary for predicting terrestrial $\mathrm{CO}_{2}$ dynamics under future climate. In this study, a TFE experiment was conducted to evaluate the soil $\mathrm{CO}_{2}$ efflux of a Korean forest ecosystem affected by changes in soil temperature, SWC, and soil bacterial activity under drought conditions.

\section{Materials and Methods}

\subsection{Site Description}

The study site was a coniferous stand in the experimental forest of the Kangwon National

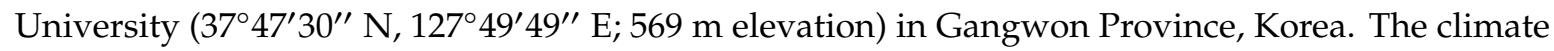
in the study site was classified as a hot summer climate (Köppen Classification) with a mean annual air temperature of $11.5^{\circ} \mathrm{C}$ (monthly averages ranged from $-9-30{ }^{\circ} \mathrm{C}$ ) and mean annual precipitation of $1450 \mathrm{~mm}$. Approximately 53\% of the rainfall occurs during the summer season. During the study period (15 July 2016-20 October 2017), the mean air temperature and total precipitation at the site were $12.1^{\circ} \mathrm{C}\left(6.8-19.7^{\circ} \mathrm{C}\right)$ and $1593.1 \mathrm{~mm}$, respectively. The soil texture was loamy and classified as B2 (Korea Forest Service). The composition of the soil was $40-55 \%$ sand, $11-14 \%$ clay, and $34-47 \%$ silt. The soil depth ranged from 30-60 cm, and the soil pH $\left(\mathrm{H}_{2} \mathrm{O}\right)$ was approximately 5.2 at the $0-30 \mathrm{~cm}$ soil depth.

The dominant tree species were 53-year-old Larix kaempferi (Lamb.) Carrière (Japanese larch) and 8-year-old Pinus koraiensis Siebold \& Zucc. (Korean pine) in the stand. The L. kaempferi trees were planted in 1964, 3.7 ha of which were subsequently thinned to give a stand density of 50 trees/ha. In 2012, 3.7 ha of P. koraiensis were planted at a density of 3000 trees/ha. In 2016, the stand density of Japanese larch was $60 \mathrm{~m}^{3} /$ ha. The canopy height of L. kaempferi ranged from 16-27 m (23 m average) and the diameter 
at breast height $(\mathrm{DBH})$ was $16-58 \mathrm{~cm}$ (34 cm average). The study area measured 0.4 ha within the 3.7 ha trimmed area, and the slope gradient ranged from 6-10\%. In addition, the main understory species were Aralia elata (Miq.) Seem., 1868, Cornus alba L., Lindera obtusiloba Blume, and Zanthoxylum schinifolium Siebold \& Zucc. The ground shrubs mainly consisted of Dryopteris crassirhizoma Nakai (1920) and Rubus crataegifolius Bunge and covered approximately $80 \%$ of the soil surface during the growing season.

\subsection{Experimental Design}

Six plots $(6 \times 6 \mathrm{~m})$ consisting of three TFE plots and three control plots were randomly constructed above forest floor in sites with similar conditions (Figure 1a,b). UV-insensitive lateral corrugated PVC panels covered the roof structures that were framed by SPVHS (steel pipe vinyl hose structures) and placed $1.5 \mathrm{~m}$ above the ground to exclude $100 \%$ of the throughfall from the exclusion plots. In addition, to prevent percolation of the surface and subsurface drainage into the TFE plots, a $0.3 \mathrm{~m}$ deep trench was dug along the outside perimeter of each TFE plot.

The trench plots (each $0.5 \times 0.5 \mathrm{~m}$ ) were established in the control and TFE plots on 10 August 2016 . The plots were dug out with a small shovel along the boundaries to a depth of $0.3 \mathrm{~m}$ below the ground surface. All the roots penetrating the trenches were cut with a steel knife but not removed. Then the trenches were backfilled with soil after covering the trench perimeter with polyethylene film to inhibit root regrowth. We cut off the aboveground parts of all plants growing in the trench plots to kill the roots. Also, new seedlings and regrowth from the roots were clipped periodically when necessary. A previous study had indicated that subterranean roots could survive and maintain their respiratory activity after trenching [39]. Therefore, to avoid respiration effects from surviving subterranean roots, we waited about eight months after trenching (26 April 2017) before we started measuring soil respiration.

The TFE roofs were installed on 15 July 2016, and measurements of soil $\mathrm{CO}_{2}$ efflux, soil temperature, and water content were conducted from 15 July 2016, to 20 October 2017 (463 days). The noticeable confounding effect of trenching operations on soil water content was not represented in the control or TFE plots (Table 1). However, air temperature under the TFE roof construction was not measured, as this would be considered an experimental artifact rather than a real environmental effect attributable to the greenhouse effect or photosynthetically active radiation (PAR). All of the measurements in the plots were taken within the core zone of each plot $(5 \times 5 \mathrm{~m})$, which was surrounded a $1 \mathrm{~m}$ wide buffer zone, to prevent edge effects. A tipping bucket rain gauge (IS-7857, Texas Electronics, Davis, CA, USA) was installed $1.5 \mathrm{~m}$ above the ground adjacent to the control and TFE plots to detect the throughfall every hour. The treatments in this study included: (1) control plot with no trench (CC), (2) control plot with trench (CT), (3) throughfall exclusion plot with no trench (TC; $100 \%$ throughfall exclusion), (4) throughfall exclusion plot with trench (TT; 100\% throughfall exclusion).

Table 1. Mean soil water content and temperature with standard errors (Avg. \pm S.E.) in the control and throughfall exclusion (TFE) plots with and without trenches under the TFE experiment (from 26 April to 20 October 2017).

\begin{tabular}{ccccc}
\hline & \multicolumn{2}{c}{ Plots with No Trench } & \multicolumn{2}{c}{ Plots with Trench } \\
\cline { 2 - 5 } & $\begin{array}{c}\text { Control } \\
(\mathbf{C C} ; \boldsymbol{n}=\mathbf{1 4})\end{array}$ & $\begin{array}{c}\text { TFE } \\
\mathbf{( T C ;} \boldsymbol{n}=\mathbf{1 4})\end{array}$ & $\begin{array}{ccc}\text { Control } \\
\mathbf{( C T} \boldsymbol{n}=\mathbf{1 4})\end{array}$ & $\begin{array}{c}\text { TFE } \\
\text { (TT; } \boldsymbol{n}=\mathbf{1 4})\end{array}$ \\
\hline Soil water content $(\%)$ & $13.9 \pm 1.0$ & $5.6 \pm 0.3$ & $13.9 \pm 0.8$ & $5.0 \pm 0.3$ \\
Soil temperature $\left({ }^{\circ} \mathrm{C}\right)$ & $17.9 \pm 1.0$ & $17.4 \pm 0.8$ & $17.9 \pm 1.0$ & $17.5 \pm 0.7$ \\
\hline
\end{tabular}

* TFE roof was installed on 15 July 2016, and the soil respiration was measured from 26 April to 20 October 2017. Control plot with no trench (CC); control plot with trench (CT); throughfall exclusion with no trench (TC); throughfall exclusion plot with trench (TT). $n$-the number of observations; Avg.- -average; S.E.-standard error 


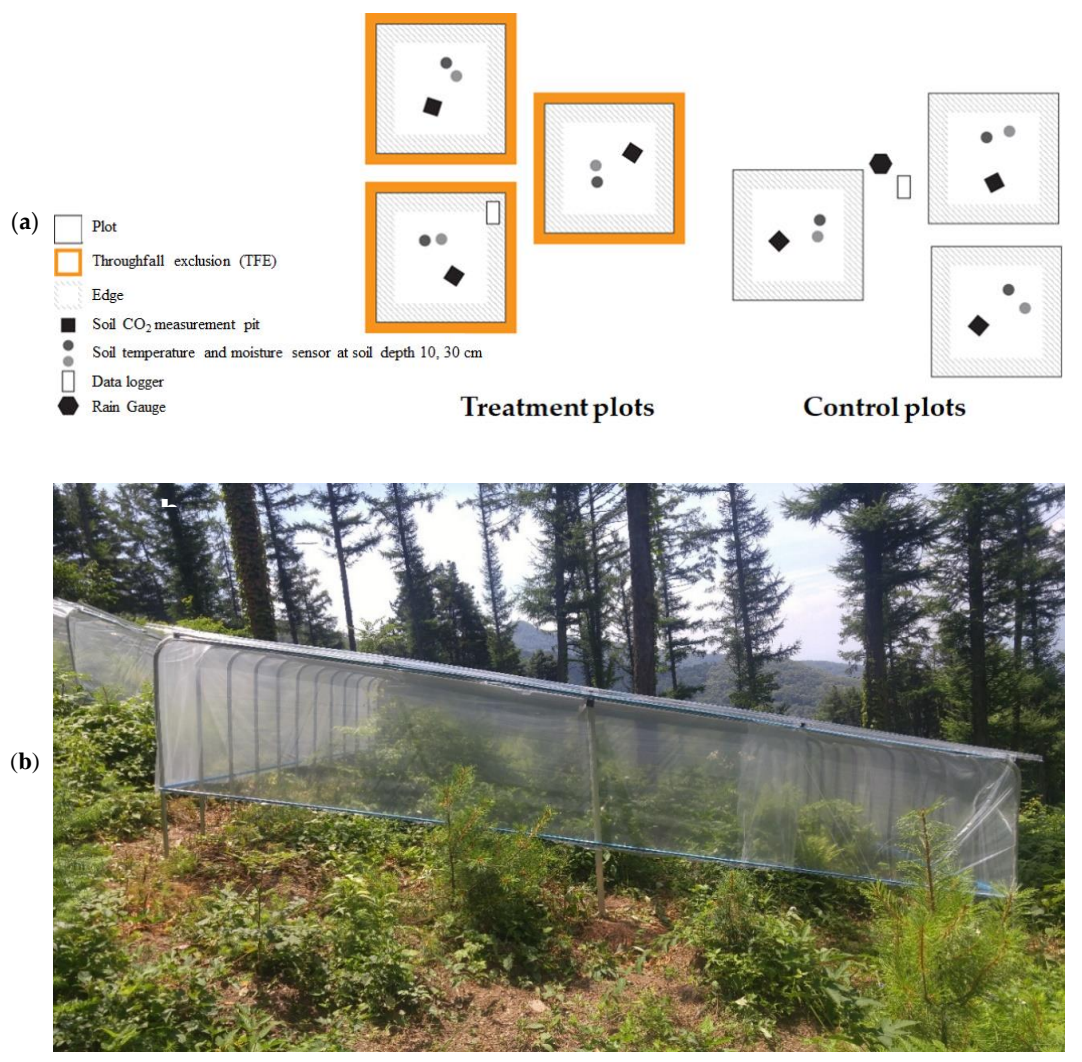

Figure 1. (a) Plot design of throughfall exclusion experiment. (b) Photograph of throughfall exclusion roof.

\subsection{Soil Physicochemical Properties}

Soil physicochemical properties were analyzed on 11 August 2016 and 8 September 2017. We did not analyze soil characteristics before conducting the TFE. Therefore, we determined the baseline characteristics using the analysis for 11 August 2016 (one month after TFE experiment began), while the analysis for 8 September 2017 served to identify the effects of the TFE treatments. However, the baseline characteristics were not the original characteristics of the TFE plots as there were rain events in July. Five pits were selected randomly in each plot, and $1 \mathrm{~kg}$ of bulk soil was collected from a depth of 0-30 cm after removing visible organic matter above the mineral soil surface. The soil samples were analyzed at a quasi-governmental organization, the Korea Forestry Promotion Institute in Seoul, Korea. Soil texture was classified by analyzing the soil physical properties. Soil $\mathrm{pH}$, nutrient parameters (organic matter $(\%)$, total nitrogen $\left(\mathrm{mg} \mathrm{kg}^{-1}\right)$, available phosphate $\left(\mathrm{mg} \mathrm{kg}^{-1}\right)$, and the cation exchange capacity $\left(\mathrm{CEC}, \mathrm{cmol} \mathrm{kg}^{-1}\right)$ ), and exchangeable cation content (i.e., $\mathrm{K}^{+}, \mathrm{Na}^{+}, \mathrm{Ca}^{2+}$, and $\mathrm{Mg}^{2+} \mathrm{cmol} \mathrm{kg}^{-1}$ ) were analyzed to evaluate soil chemical properties.

\subsection{Tree Growth}

We measured the growth of 15 P. koraiensis trees in the control plots and 19 trees in the TFE plots. These measurements were taken on 7 September 2016, 31 May 2017, and 20 October 2017. Given that the Korean pine saplings were too small to measure DBH, the root collar (basal tree area, measured from just above the forest floor) diameter of $P$. koraiensis was measured using a $1 \mathrm{~mm}$ diameter yarn to examine the effect of drought stress on radial growth of saplings [40]. This study used tree growth, defined as the difference between the first and last measurements, to examine the effect of the TFE treatments. 


\subsection{Soil Moisture and Soil Temperature}

Soil water content and temperature were measured from 15 July 2016 to 20 October 2017. Probe sensors (1000A, IStech, Goyangsi, Korea) were inserted horizontally at a soil cross section of $10 \mathrm{~cm}$ and $30 \mathrm{~cm}$ depth per plot to measure soil water content and temperature each hour, and the data were collected with data loggers (GL840, Graphtech, Germany; Figure 2). From December 2016 to February 2017, data collection was temporarily interrupted given that it was impossible to replace batteries due to the snowfall.

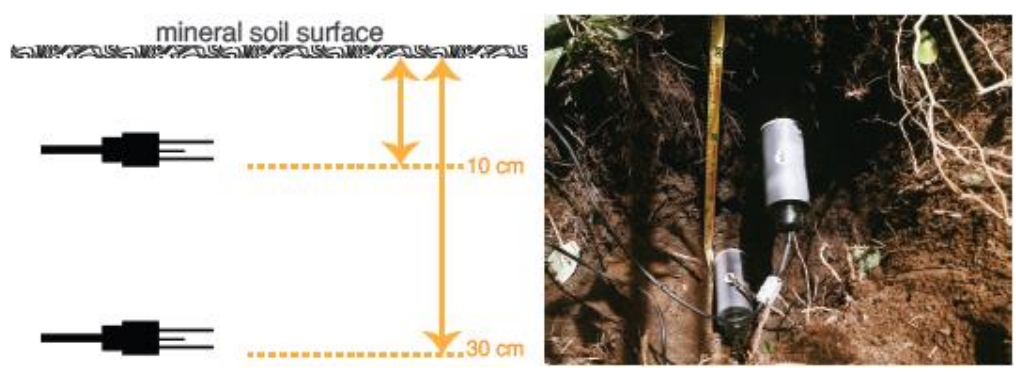

Figure 2. Logging system of sensors to measurement soil water content and soil temperature.

\subsection{Soil $\mathrm{CO}_{2}$ Measurement}

Total SR in the soil was measured by partitioning soil HR from that of microbial respiration and AR from that of root respiration. SR was calculated from the measurements of every plot with no root trenching, and HR was obtained for both the control and TFE plots with root trenching. We dug soil pits $\left(40 \mathrm{~cm}^{3}\right)$ to trench the root so that the HR and AR efflux could be calculated individually.

Soil $\mathrm{CO}_{2}$ effluxes were measured at the soil surface on one day every 2 weeks (total of 14 sampling days) during the growing season (April-October 2017). All measurements were conducted during daylight hours (12:00 to 16:00) using a carbon dioxide probe for demanding measurements (GMP 343, Vaisala CARBOCAP ${ }^{\circledR}$, Helsinki, Finland). The PVC chambers measured $16 \mathrm{~cm}$ in length and $13 \mathrm{~cm}$ in diameter. The chambers were embedded $1.4 \mathrm{~cm}$ into the soil surface and closed after inserting the carbon dioxide probe, and measured for $5 \mathrm{~min}$.

Closed dynamic chambers were used to calculate the soil $\mathrm{CO}_{2}$ efflux [41]. With this method, the flux was calculated from the rate of change of the $\mathrm{CO}_{2}$ concentration (ppm) with Equation (1):

$$
F_{c, s}=\frac{\partial\left[\mathrm{CO}_{2}\right]_{c}}{\partial \mathrm{t}}\left(\frac{m_{w}}{m_{v}}\right)\left(\frac{V}{A}\right)
$$

where $V$ is the total chamber volume of the system, $A$ is the area covered by the chamber, $m_{w}$ is the molecular weight, and $m_{v}$ is the $\mathrm{CO}_{2}$ volume.

The soil $\mathrm{CO}_{2}$ concentration was measured during an average of $5 \mathrm{~min}$ at $5 \mathrm{~s}$ intervals through the headspace of the chamber. The soil $\mathrm{CO}_{2}$ efflux was calculated from the linear increase of the $\mathrm{CO}_{2}$ concentration with Equation (2):

$$
R_{s}=\mathrm{CO}_{2} \text { efflux }\left(\mathrm{mg} \mathrm{C} m^{-2} h r^{-1}\right)=E x+E_{i}
$$

where $R_{S}$ represents measured soil respiration (SR, HR, and AR, respectively), $E$ is the increase of the soil $\mathrm{CO}_{2}$ efflux measured at 5-s intervals, and $E_{i}$ is the initial soil $\mathrm{CO}_{2}$ efflux. We had looked at the rates of soil $\mathrm{CO}_{2}$ efflux over time and calculated with linear regression up to a point where flux starts to slow down.

\subsection{Microbial Activity}

The soil bacterial community was analyzed to examine the responses of soil microbes to drought conditions. Soil samples were collected 1 month after commencement of the TFE experiment 
(August 2016) and approximately 1 year after the TFE experiment began (September 2017). The soil samples were collected with $50 \mathrm{~mL}$ Falcon tubes from the $10 \mathrm{~cm}$ soil depth and kept at $-35{ }^{\circ} \mathrm{C}$ in a refrigerator. All soil samples were analyzed at a commercial laboratory (ChunLab, Inc., Seoul, Korea) in September 2017.

PCR amplification was conducted using primers that targeted from the V3 to V4 regions of the 16S rRNA gene after extracting the DNA from the soil samples. For bacterial amplification, the 341F (5'-TCGTCGGCAGCGTC-AGATGTGTATAAGAGACAG-CCTACGGGNGGCWGCAG-3'; underlining sequence indicates the target region primer) and 805R (5'-GTCTCGTGGGCTCGGAGATGTGTATAAGAGACAG-ACTACHVGGGTATCTAATCC-3') primers were employed. The amplifications were carried out with the following conditions: initial denaturation at $95{ }^{\circ} \mathrm{C}$ for $3 \mathrm{~min}$, followed by 25 cycles of denaturation at $95{ }^{\circ} \mathrm{C}$ for $30 \mathrm{~s}$, primer annealing at $55{ }^{\circ} \mathrm{C}$ for $30 \mathrm{~s}$, extension at $72{ }^{\circ} \mathrm{C}$ for $30 \mathrm{~s}$, and a final elongation at $72{ }^{\circ} \mathrm{C}$ for $5 \mathrm{~min}$. Then, a secondary amplification was conducted to attach the Illumina NexTera barcode through the i5 forward primer (5'-AATGATACGGCGACCACCGAGATCTACAC-XXXXXXXXX-TCGTCGGCAGCGTC-3'; $X$ indicates the barcode region) and the i7 reverse primer (5'-CAAGCAGAAGACGGCATACGAGATXXXXXXXX-AGTCTCGTGGGCTCGG-3'). The secondary amplification conditions were the same as those for the primary amplification except that the amplification cycle was set to 8 .

The PCR product was confirmed with visualization under a Gel Doc system (BioRad, Hercules, CA, USA) using $2 \%$ agarose gel electrophoresis. The amplified products were purified using the QIAquick PCR purification kit (Qiagen, Valencia, CA, USA). The purified products with equal concentrations were pooled together and short fragments were removed (non-target products) with an Ampure bead kit (Agencourt Bioscience, Beverly, MA, USA). Quality and product size were estimated using a Bioanalyzer 2100 (Agilent, Palo Alto, CA, USA) with a DNA 7500 chip. The pooled mixed amplicons were sequenced at Chunlab, Inc. using an Illumina MiSeq Sequencing system (Illumina, San Diego, CA, USA) according to the instructions from the manufacturer.

Changes in the soil bacterial community between the control and treatment plots after the 13-month TFE experiment were compared using the Shannon-Weaver diversity index $\left(\mathrm{H}^{\prime}\right.$; [42]). The Shannon-Weaver index takes into account both richness and evenness measurements of the species present. The $\mathrm{H}^{\prime}$ is defined in Equation (3):

$$
H^{\prime}=-\sum_{i=1}^{S} p_{i} \times \log \left(p_{i}\right)
$$

where $p_{i}$ is the relative abundance of the $i$-th species, and $S$ is the total number of species in the soil sample.

Uniformity based on the Pielou Index [43] was used to quantify how equal the soil bacterial community was numerically. The Pielou evenness index is defined in Equation (4):

$$
\mathrm{e}=\frac{H^{\prime}}{\ln S^{\prime}}
$$

where $H^{\prime}$ is the Shannon-Weaver Diversity Index, and $S^{\prime}$ is the number of species in the sample.

\subsection{Data Analysis}

Monthly average data for soil $\mathrm{CO}_{2}$ efflux, soil temperature, and soil water content were calculated as the means of the three replicated control and TFE plots to avoid pseudo-replication. The Anderson-Darling normal distribution test was used to evaluate normality, and the Bartlett test was used to evaluate homogeneity of variance. To evaluate differences in sapling diameter growth among the control and TFE plots under drought conditions, we used Student's $t$-test to analyze the average data of tree sapling growth obtained on each day of measurement. Also, a Student's t-test was used to evaluate differences in soil respiration, temperature, and water content. In addition, we used single 
linear regression and multiple nonlinear regression analyses to estimate the relationships between SR and soil temperature and water content. A multiple nonlinear regression was used to estimate the combined effects of soil temperature and water content on soil respiration. The nonlinear regression model used a Gaussian method and is shown in Equation (5):

$$
z=a \times \exp \left(-0.5\left[\left(\frac{x-x_{0}}{b}\right)^{2}+\left(\frac{y-y_{0}}{c}\right)^{2}\right]\right)
$$

where $z$ is measured soil respiration, $x$ is measured soil temperature, and $y$ is measured soil water content.

All analyses were conducted in $\mathrm{R} v$. 3.6.0, and significance was set at $p \leq 0.05$. The multiple nonlinear regression was generated using a Sigmaplot Demo (Systat Software, Inc., San Jose, CA, USA) for Windows (Microsoft, Redmond, WA, USA) software.

To assess the effects of soil temperature on soil respiration, a first-order exponential function $\mathrm{Q}_{10}$ was fitted to the equation:

$$
R_{s}=\beta_{0} \times \exp \left(\beta_{1} \cdot T_{s}\right)
$$

where $R_{S}$ represents measured soil respiration (SR, HR, and AR, respectively), $\beta_{0}$ and $\beta_{1}$ are the fitted parameters, and $T_{S}$ is the measured soil temperature. $Q_{10}$ values were derived using the equation:

$$
\mathrm{Q}_{10}=\exp \left(10 \cdot \beta_{1}\right)
$$

Given that soil respiration in the control and TFE treatment plots was measured at different times of day (12:00 to 16:00), it is probable that temperatures differed at the time of measurement. To control for differences in temperature when analyzing the effects of soil water content on SR, HR, and AR in the control and TFE plots, respiration values were normalized to the daily mean soil temperature using $\mathrm{Q}_{10}$ values. In addition, we used $R_{10}$ to assess the effect of soil water content on SR, HR, and AR in the control and TFE plots without confounding effects based on the modified normalization Equation (8):

$$
R_{\text {norm }}=R_{10} \times Q_{10}\left(\left(T_{\text {daymean }}-T_{s}\right) / 10\right)
$$

where $R_{10}$ is the soil respiration $\left(\mathrm{mg} \mathrm{C} \mathrm{m}^{-2} \mathrm{~h}^{-1}\right)$ normalized to a soil temperature of $10^{\circ} \mathrm{C}, T_{S}$ is the measured soil temperature $\left({ }^{\circ} \mathrm{C}\right)$, and $T_{\text {daymean }}$ is the average daily soil temperature $\left({ }^{\circ} \mathrm{C}\right)$ during the measurement period.

The covariance structures of nonlinear regression Equations (5) and (6) were chosen by minimizing corrected Akaike information criteria (AICC) [10].

\section{Results}

\subsection{Effects of Throughfall Exclusion on Soil Physicochemical Properties}

The soil physicochemical properties showed no notable changes in the control and TFE plots during the experimental period (393 days). The baseline soil physicochemical properties measured one month after the TFE experiment began were not notably different between the control and TFE plots, except for the available soil phosphate (Table 2). After approximately one year, available soil phosphate decreased approximately $40 \%$ in the control plots, but there were no differences present in the TFE plots. Over the same period, soil nitrogen increased approximately 3-fold in the control plots, while only slightly increasing in the TFE plots. In both control and TFE plots, the exchangeable $\mathrm{Na}^{+}, \mathrm{Ca}^{2+}$, and $\mathrm{Mg}^{2+}$ concentrations slightly increased over the year of the study, but the exchangeable $\mathrm{K}^{+}$concentration decreased during the same period. 
Table 2. Soil physical and chemical properties (Avg.. S.E.) in the control and TFE plots during the TFE experiment.

\begin{tabular}{|c|c|c|c|c|c|}
\hline \multirow{3}{*}{\multicolumn{2}{|c|}{$\begin{array}{l}\text { Soil Physical/ } \\
\text { Chemical } \\
\text { Characteristics }\end{array}$}} & \multicolumn{4}{|c|}{ Treatment/Sampling Day } \\
\hline & & \multicolumn{2}{|c|}{ Control Plot $(n=3)$} & \multicolumn{2}{|c|}{ TFE Plot $(n=3)$} \\
\hline & & 11 August 2016 & 8 September 2017 & 11 August 2016 & 8 September 2017 \\
\hline \multicolumn{2}{|c|}{ Sand (\%) } & $45.2 \pm 4.7$ & $45.6 \pm 4.2$ & $42.4 \pm 1.5$ & $42.2 \pm 3.1$ \\
\hline \multicolumn{2}{|c|}{ Silt (\%) } & $42.3 \pm 4$ & $42.3 \pm 3.2$ & $44.2 \pm 1.4$ & $44.6 \pm 3.0$ \\
\hline \multicolumn{2}{|c|}{ Clay (\%) } & $12.5 \pm 0.7$ & $12.1 \pm 1.1$ & $13.4 \pm 0.1$ & $13.2 \pm 0.3$ \\
\hline \multicolumn{2}{|c|}{ Soil texture } & L or SL & L or SL & L & SiL or $\mathrm{L}$ \\
\hline \multicolumn{2}{|c|}{$\mathrm{pH}$} & $5.2 \pm 0.1$ & $5 \pm 0.1$ & $5.2 \pm 0.0$ & $4.9 \pm 0.0$ \\
\hline \multicolumn{2}{|c|}{ Organic matter $(\mathrm{mg} / \mathrm{kg})$} & $6.21 \pm 1.48$ & $6.36 \pm 0.80$ & $6.88 \pm 0.62$ & $6.87 \pm 0.5$ \\
\hline \multicolumn{2}{|c|}{$\mathrm{N}(\mathrm{mg} / \mathrm{kg})$} & $0.23 \pm 0.04$ & $0.70 \pm 0.36$ & $0.25 \pm 0.02$ & $0.38 \pm 0.03$ \\
\hline \multicolumn{2}{|c|}{$\mathrm{P}(\mathrm{mg} / \mathrm{kg})$} & $22.3 \pm 3.5$ & $15.6 \pm 3.9$ & $11.7 \pm 1.5$ & $11.6 \pm 1.0$ \\
\hline \multicolumn{2}{|c|}{$\mathrm{CEC}(\mathrm{cmol} / \mathrm{kg})$} & $14.5 \pm 1.9$ & $13.8 \pm 1.0$ & $14.7 \pm 0.2$ & $14.2 \pm 0.6$ \\
\hline \multirow{4}{*}{$\begin{array}{c}\text { Exchangeable } \\
\text { cation } \\
(\mathrm{cmol} / \mathrm{kg})\end{array}$} & $\mathrm{K}^{+}$ & $0.23 \pm 0.03$ & $0.11 \pm 0.01$ & $0.2 \pm 0.01$ & $0.14 \pm 0.00$ \\
\hline & $\mathrm{Na}^{+}$ & $0.04 \pm 0.00$ & $0.05 \pm 0.00$ & $0.04 \pm 0.00$ & $0.06 \pm 0.00$ \\
\hline & $\mathrm{Ca}^{2+}$ & $0.93 \pm 0.25$ & $1.29 \pm 0.10$ & $1.16 \pm 0.25$ & $1.56 \pm 0.19$ \\
\hline & $\mathrm{Mg}^{2+}$ & $0.12 \pm 0.05$ & $0.22 \pm 0.01$ & $0.14 \pm 0.06$ & $0.21 \pm 0.04$ \\
\hline
\end{tabular}

n-the number of replicates; CEC—cation exchange capacity; L—loam; SL—sandy loam; SiL—silt loam; Avg.- -average; S.E.--standard error.

In this site, soil pH fell within the soil pH range for Gangwon Province, and CEC was within the optimal soil property value range for vegetation growth at the end of the TFE experiment [44]. In contrast, at the beginning of the TFE experiment, the concentrations of exchangeable cations in the control and TFE plots did not fall within this range [44]. On the other hand, soil organic matter content exceeded 3\%, which is the optimal value for vegetation growth [44]. In addition, at the start of the experiment, available soil phosphate was $30 \%$ lower than the optimal values $\left(100-200 \mathrm{mg} \mathrm{kg}^{-1}\right)$ in the control and TFE plots [44]. Available soil phosphate, one of the soil nutrient parameters, was $30 \%$ lower than the optimal values (100-200 mg kg$\left.{ }^{-1}\right)$ at the beginning of the experiment in both control and TFE plots.

\subsection{Seasonal Variation in Soil Moisture, Soil Temperature, and Soil Respiration}

Daily mean precipitation and air temperature, volumetric soil moisture content, and soil temperature were measured from July 2016 to November 2016 and from March 2017 to October 2017 (Figure 3). In the TFE plots, soil water content decreased while soil temperature showed no differences compared with that of the control plots during the TFE experiment. At the end of the TFE experiment, the mean soil water content of the TFE plots significantly decreased at the $10 \mathrm{~cm}(7 \%)$ and $30 \mathrm{~cm}$ depths (16\%) compared with that of the control plots $(26.2 \%$ and $22.8 \%$ at the $10 \mathrm{~cm}$ and $30 \mathrm{~cm}$ depths, respectively), and the soil water content between the $10 \mathrm{~cm}$ and $30 \mathrm{~cm}$ soil depths was significantly different in the TFE plots. Mean daily soil temperatures at the $10 \mathrm{~cm}$ and $30 \mathrm{~cm}$ soil depths were 16.9 and $16.1{ }^{\circ} \mathrm{C}$, respectively, in the TFE plots and 16.6 and $16.7^{\circ} \mathrm{C}$, respectively, in the control plots (Table 2).

Measurement of the highest and lowest values in each of the study years revealed that in 2016, the mean soil temperature in control plots was highest in August $\left(23.5^{\circ} \mathrm{C}\right)$ and lowest in November $\left(8.9^{\circ} \mathrm{C}\right)$, whereas in 2017 , soil temperature was highest in July $\left(22.7^{\circ} \mathrm{C}\right)$ and lowest in March $\left(3.8^{\circ} \mathrm{C}\right)$. In the TFE plots, in both 2016 and 2017, the mean soil temperature was highest in August $\left(23.7^{\circ} \mathrm{C}\right.$ and $22.2{ }^{\circ} \mathrm{C}$, respectively), and was lowest in November in $2016\left(10.7^{\circ} \mathrm{C}\right)$ and March in $2017\left(5.6^{\circ} \mathrm{C}\right)$ (Table 3). In control plots, mean soil water content was highest in November in 2016 (33.1\%) and April in 2017 (32.3\%) and was lowest in July in 2016 (22.3\%) and June in 2017 (11.8\%). In the TFE plots, soil water content was highest in July (18.0\%) and lowest in November (2.6\%) in 2016, and highest in September (11.1\%) and lowest in June (3.2\%) in 2017 (Table 3). 
(a)

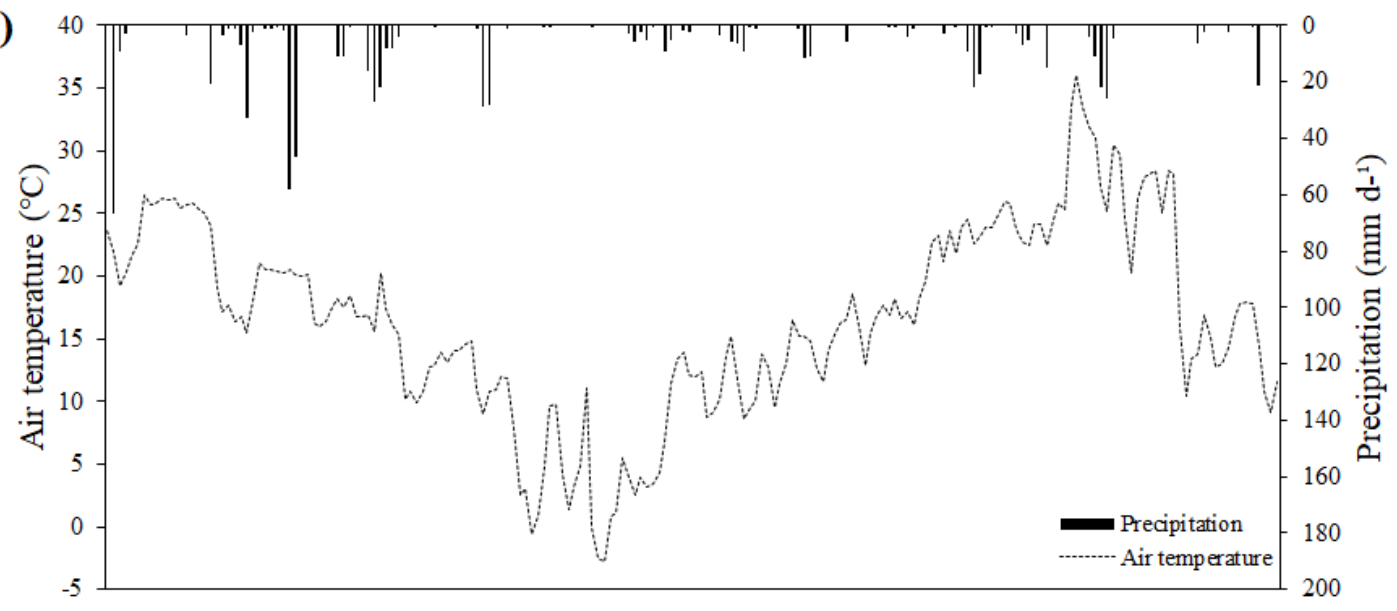

(b)

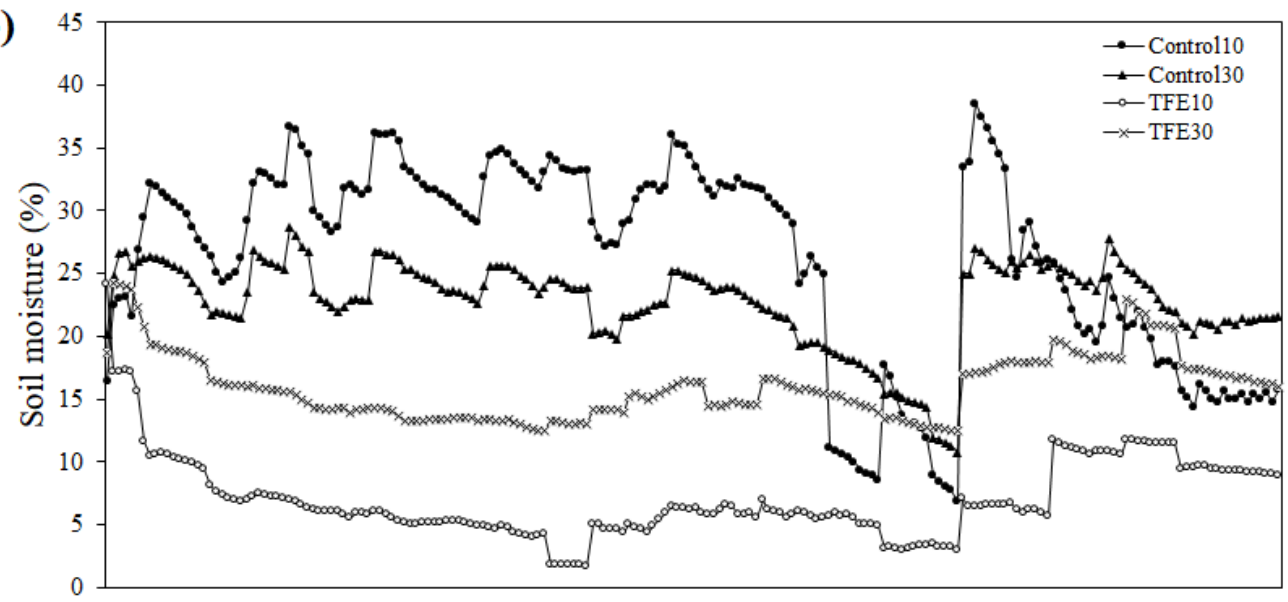

(c)

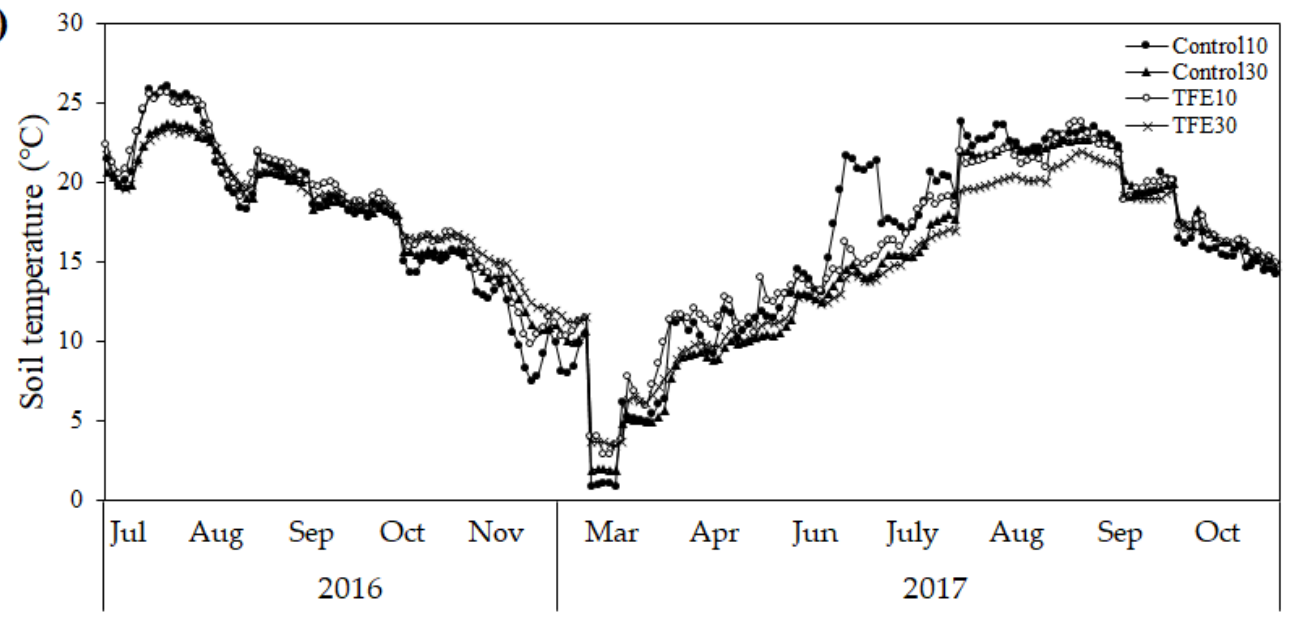

Figure 3. Seasonal variation of (a) daily mean air temperature and precipitation, (b) soil water content, (c) soil temperature in the control and TFE plots. Control10, TFE10 and Control30, TFE30 represent the mean value at $10 \mathrm{~cm}$ and $30 \mathrm{~cm}$ soil depth in the control plots and TFE plots, respectively. Each value is average of three replications for each plot.

SR and HR were significantly higher in the control plots than in the TFE plots $(p<0.05)$. The SR, HR were inhibited more than $50 \%$ in the TFE plots compared with that of the control plots. While AR was not significantly inhibited in TFE plots (37\%) compared with control plots (Table 4).

In the control plots, soil respiration and its component values decreased in June when mean soil water content was at its lowest, and increased with increasing soil water content, such that the highest 
soil respiration was recorded in July when the mean soil temperature was highest. Similarly, in the TFE plots, we recorded high soil respiration values in July and August, when the average soil temperature was high (Figure 4).
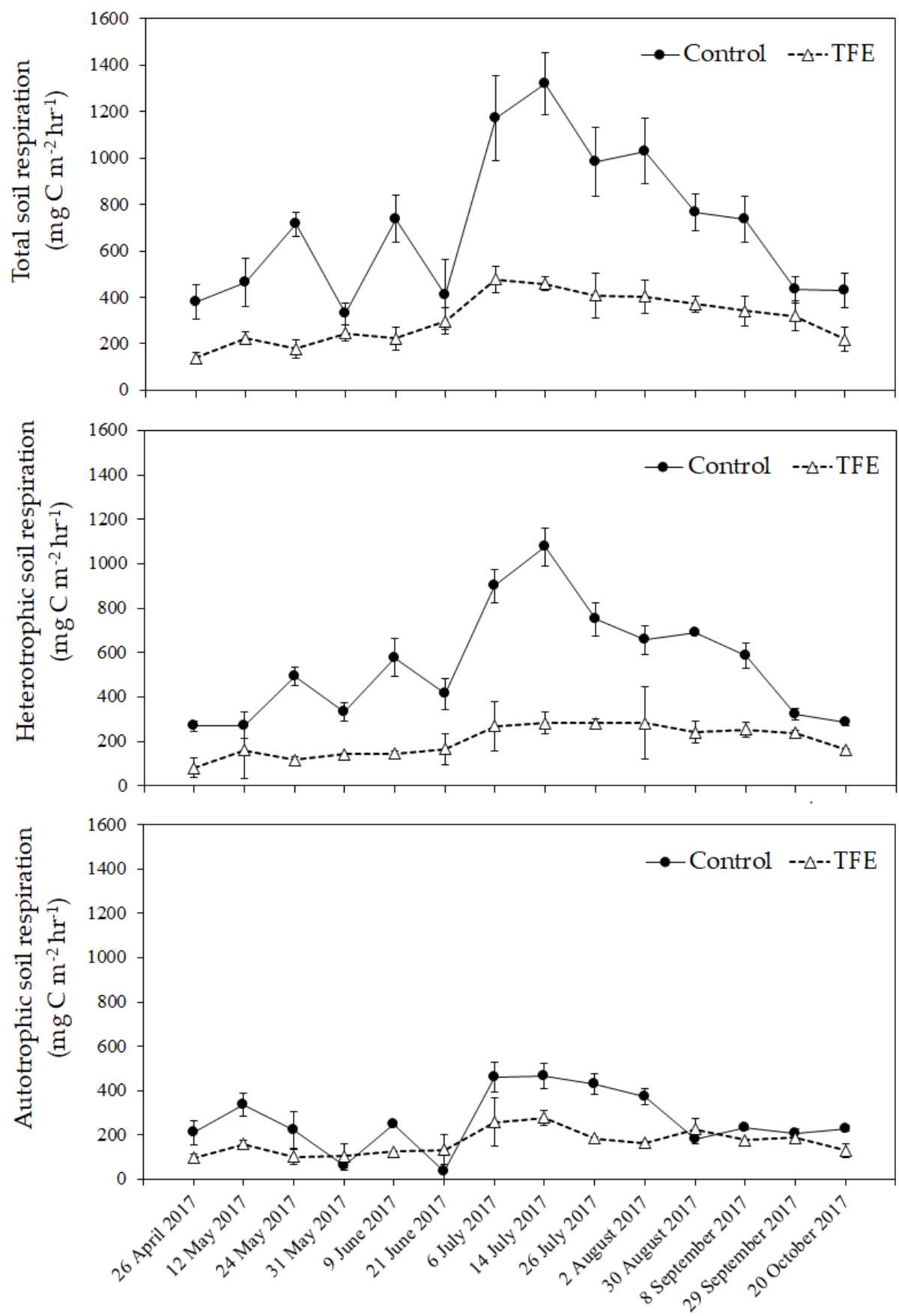

Figure 4. Seasonal variation in soil respiration (soil $\mathrm{CO}_{2}$ efflux) in control and throughfall exclusion (TFE) plots during the 2017 growing season. 
Table 3. Averages of soil water content, soil temperature with standard errors (Avg. \pm S.E.) in the control and TFE plots during the TFE experiment.

\begin{tabular}{|c|c|c|c|c|c|c|c|c|c|c|c|}
\hline \multirow{4}{*}{ Year } & \multirow{4}{*}{ Month } & \multirow{4}{*}{$\begin{array}{l}\text { Precipitation } \\
\text { (mm) }\end{array}$} & \multirow{4}{*}{$\begin{array}{c}\text { Air Temperature } \\
\left({ }^{\circ} \mathrm{C}\right)\end{array}$} & \multicolumn{4}{|c|}{ Control } & \multicolumn{4}{|c|}{ Throughfall Exclusion } \\
\hline & & & & \multicolumn{8}{|c|}{ Soil Depth (cm) } \\
\hline & & & & 10 & 30 & 10 & 30 & 10 & 30 & 10 & 30 \\
\hline & & & & \multicolumn{2}{|c|}{ Soil Temperature $\left({ }^{\circ} \mathrm{C}\right)$} & \multicolumn{2}{|c|}{ Soil Moisture (\%) } & \multicolumn{2}{|c|}{ Soil Temperature $\left({ }^{\circ} \mathrm{C}\right)$} & \multicolumn{2}{|c|}{ Soil Moisture (\%) } \\
\hline \multirow{5}{*}{2016} & July ** & 151.3 & $21.6 \pm 0.6$ & $20.9 \pm 0.5$ & $20.3 \pm 0.2$ & $22.3 \pm 1.3$ & $25.0 \pm 0.9$ & $21.6 \pm 0.4$ & $20.5 \pm 0.3$ & $18 \pm 1.1$ & $22.8 \pm 0.8$ \\
\hline & August & 51.7 & $23.2 \pm 0.9$ & $23.5 \pm 0.6$ & $22.5 \pm 0.3$ & $28.3 \pm 0.6$ & $24.0 \pm 0.5$ & $23.7 \pm 0.5$ & $22.4 \pm 0.3$ & $9.2 \pm 0.4$ & $18.0 \pm 0.3$ \\
\hline & September & 128.1 & $18.6 \pm 0.4$ & $19.7 \pm 0.3$ & $19.5 \pm 0.2$ & $32 \pm 0.6$ & $24.8 \pm 0.5$ & $20.3 \pm 0.2$ & $19.7 \pm 0.2$ & $6.6 \pm 0.1$ & $15.0 \pm 0.2$ \\
\hline & October & 86.6 & $12.8 \pm 0.7$ & $15.0 \pm 0.4$ & $15.8 \pm 0.3$ & $32.8 \pm 0.4$ & $24.7 \pm 0.2$ & $16.1 \pm 0.4$ & $16.5 \pm 0.3$ & $5.2 \pm 0.1$ & $13.5 \pm 0.1$ \\
\hline & November & 18.8 & $4.7 \pm 1.1$ & $8.9 \pm 0.3$ & $10.7 \pm 0.2$ & $33.1 \pm 0.2$ & $24.1 \pm 0.1$ & $10.7 \pm 0.2$ & $11.8 \pm 0.2$ & $2.6 \pm 0.3$ & $12.9 \pm 0.1$ \\
\hline \multirow{8}{*}{2017} & March & 15.9 & $2.3 \pm 0.8$ & $3.8 \pm 0.6$ & $3.8 \pm 0.4$ & $29.8 \pm 0.5$ & $21.4 \pm 0.3$ & $5.6 \pm 0.6$ & $5.2 \pm 0.4$ & $4.9 \pm 0.1$ & $14.8 \pm 0.2$ \\
\hline & April & 54.8 & $11.6 \pm 0.4$ & $11.1 \pm 0.2$ & $9.6 \pm 0.2$ & $32.3 \pm 0.4$ & $23.5 \pm 0.3$ & $11.9 \pm 0.2$ & $10.1 \pm 0.2$ & $6.1 \pm 0.1$ & $15.6 \pm 0.2$ \\
\hline & May & 32.3 & $15.2 \pm 0.5$ & $17.4 \pm 0.9$ & $13.5 \pm 0.2$ & $16.3 \pm 2.0$ & $18.6 \pm 0.3$ & $14.4 \pm 0.2$ & $13.1 \pm 0.2$ & $5.5 \pm 0.1$ & $15.1 \pm 0.2$ \\
\hline & June & 32.5 & $19.5 \pm 0.7$ & $18.5 \pm 0.4$ & $16.3 \pm 0.3$ & $11.8 \pm 1.0$ & $13.7 \pm 0.5$ & $17.6 \pm 0.3$ & $15.8 \pm 0.3$ & $3.2 \pm 0.0$ & $13.0 \pm 0.1$ \\
\hline & July & 520 & $24 \pm 0.3$ & $22.7 \pm 0.2$ & $22.0 \pm 0.1$ & $31.8 \pm 1.2$ & $25.8 \pm 0.2$ & $21.5 \pm 0.1$ & $19.9 \pm 0.1$ & $6.4 \pm 0.1$ & $17.6 \pm 0.1$ \\
\hline & August & 346.4 & $28.1 \pm 1.1$ & $22.4 \pm 0.4$ & $22.2 \pm 0.2$ & $22.3 \pm 0.5$ & $25.3 \pm 0.3$ & $22.2 \pm 0.4$ & $21.0 \pm 0.2$ & $10.7 \pm 0.4$ & $19.2 \pm 0.4$ \\
\hline & September & 39.8 & $24.3 \pm 2.1$ & $19.0 \pm 0.5$ & $19.2 \pm 0.3$ & $18.3 \pm 0.7$ & $22.7 \pm 0.4$ & $19.3 \pm 0.4$ & $18.7 \pm 0.3$ & $11.1 \pm 0.3$ & $20.3 \pm 0.5$ \\
\hline & October & 34.4 & $14.4 \pm 0.7$ & $15.4 \pm 0.2$ & $16.1 \pm 0.2$ & $15.2 \pm 0.1$ & $21.2 \pm 0.1$ & $16.2 \pm 0.2$ & $16.0 \pm 0.2$ & $9.2 \pm 0.1$ & $16.7 \pm 0.1$ \\
\hline Total & & 1512.6 & & & & & & & & & \\
\hline Mean & & & $16.6 \pm 0.6$ & $16.7 \pm 0.4$ & $16.1 \pm 0.4$ & $26.2 \pm 0.6^{a, *}$ & $22.8 \pm 0.2^{a, b, *}$ & $16.9 \pm 0.4$ & $16.1 \pm 0.3$ & $7 \pm 0.2^{c, *}$ & $16 \pm 0.2^{\mathrm{d}, *}$ \\
\hline
\end{tabular}

* Different letters indicate significantly different between soil depth within soil temperature and moisture $(p<0.05)$ at 0.05 level. ${ }^{* *}$ The TFE roof was installed on 15 July 2016 , and the data presented in the table were obtained during the period from 15 July 2016 to 20 October 2017 (463 days).

Table 4. Probabilities of the nonlinear relationships between measured soil respiration $\left(R_{S}\right)$ and soil temperature (Equation (6)) or combined effect of soil temperature and water content (Equation (5)).

\begin{tabular}{|c|c|c|c|c|c|c|c|c|c|}
\hline \multirow[b]{2}{*}{ Plot } & & \multirow{2}{*}{$\begin{array}{c}R_{S} \\
\text { (Avg. } \pm \text { S.E.) }\end{array}$} & \multicolumn{3}{|c|}{ Equation (5) } & \multicolumn{4}{|c|}{ Equation (6) } \\
\hline & & & $\mathbf{R}^{2}$ & $p$ & AICC & $\mathbf{R}^{2}$ & $p$ & AICC & $\mathbf{Q}_{10}$ \\
\hline \multirow{3}{*}{ Control } & SR & $707.61 \pm 82.05$ & 0.89 & $<0.01$ & 5.5 & 0.61 & $<0.001$ & 180.8 & 2.48 \\
\hline & HR & $543.86 \pm 64.57$ & 0.76 & $<0.01$ & 8.1 & 0.66 & $<0.001$ & 173.0 & 2.51 \\
\hline & $\mathrm{AR}$ & $263.39 \pm 34.47$ & & & & 0.31 & $<0.001$ & 164.5 & 2.20 \\
\hline \multirow{3}{*}{ TFE } & SR & $307.69 \pm 27.47$ & 0.88 & $<0.01$ & -21 & 0.82 & $<0.001$ & 148.3 & 2.86 \\
\hline & HR & $201.43 \pm 17.89$ & 0.88 & $<0.01$ & -21.9 & 0.74 & $<0.001$ & 136.5 & 2.69 \\
\hline & $\mathrm{AR}$ & $165.84 \pm 14.66$ & & & & 0.43 & $<0.001$ & 148.0 & 2.14 \\
\hline
\end{tabular}

SR—total soil respiration; $\mathrm{HR}$-heterotrophic soil respiration; AR—autotrophic soil respiration; AICC—corrected Akaike information criteria; $\mathrm{Q}_{10}$-temperature sensitivity index; $\mathrm{R}^{2}$ —coefficient of determination; $p$ - $p$-value; Avg.—average; S.E.—-standard error 
3.3. Effects of Throughfall Exclusion on the Relationship between Soil $\mathrm{CO}_{2}$ Efflux, Soil Temperature, and Soil Moisture

From April to October in 2017 under the TFE experiment, the soil $\mathrm{CO}_{2}$ efflux showed a significant and positive correlation with soil temperature in all control and treatment plots $(p<0.001)$ (Figure 5). The exponential regression Equation (6) showed a high coefficient of determination about all of $R_{S}$ and was a better fit according to AICC values in the TFE plots compared with that of the control plots (Table 4, Figure 5). Furthermore, compared with the control plots, we detected no significant reductions in the $Q_{10}$ values of SR and HR in the TFE plots, despite a reduction in soil respiration recorded in the TFE plots (Table 4, Figure 5). There was no obvious relationship between soil water content and normalized soil respiration, and only AR in the control plots showed a significant correlation with soil water content (Figure 6).

The combined effect of soil temperature and water content was better able not only to explain the SR and HR but also fit for data by using Equation (6) (according to $\mathrm{R}^{2}$ and AICC values) at $p<0.01$ (Table 4, Figure 7). The multiple nonlinear regression model was not appropriate for describing the relationship between $\mathrm{AR}$ and soil temperature and water content. In the control plots, SR and HR increased as the soil temperature and water content increased until the soil water content reached approximately $16 \%$, after which soil respiration decreased (Figure $7 \mathrm{a}$ ). In the TFE plots, SR and HR increased until the soil water content reached about $5 \%$ and $6 \%$, respectively (Figure $7 \mathrm{~b}$ ).
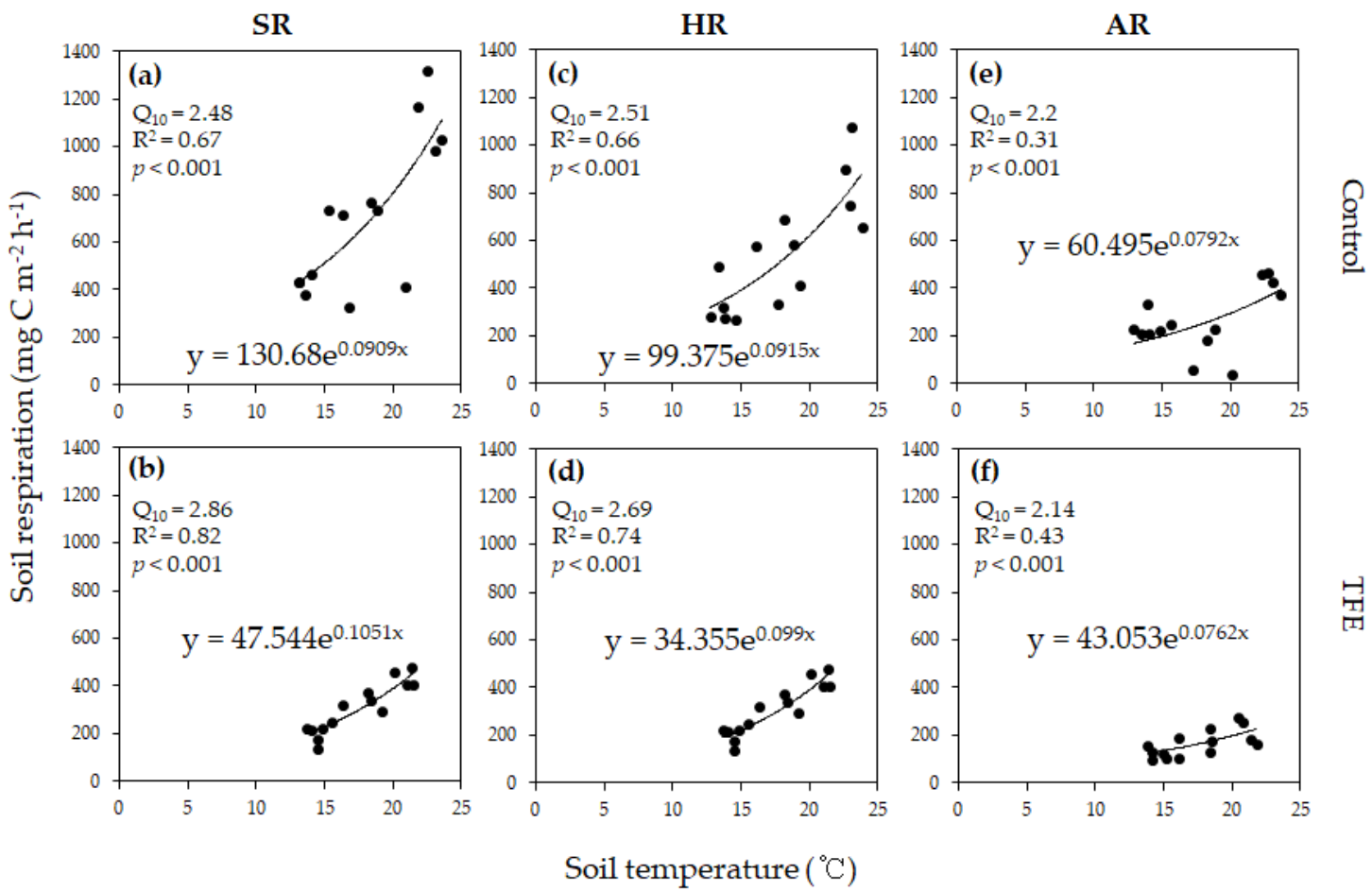

Figure 5. Soil temperature dependency of $(\mathbf{a}, \mathbf{b})$ total soil respiration (SR), (c,d) heterotrophic soil respiration (HR), (e,f) autotrophic soil respiration (AR) in control and throughfall exclusion (TFE) plots. Exponential function is $y=\beta_{0} \times \exp \left(\beta_{1} \cdot x\right) ; y$ is measured soil respiration $\left(R_{S}\right), x$ is soil temperature and $\beta_{0}$ and $\beta_{1}$ are fitted parameters. $Q_{10}$ function is $Q_{10}=\exp \left(10 \cdot \beta_{1}\right)$. $R^{2}$ is coefficient of determination and $p$ represents $p$-value. 

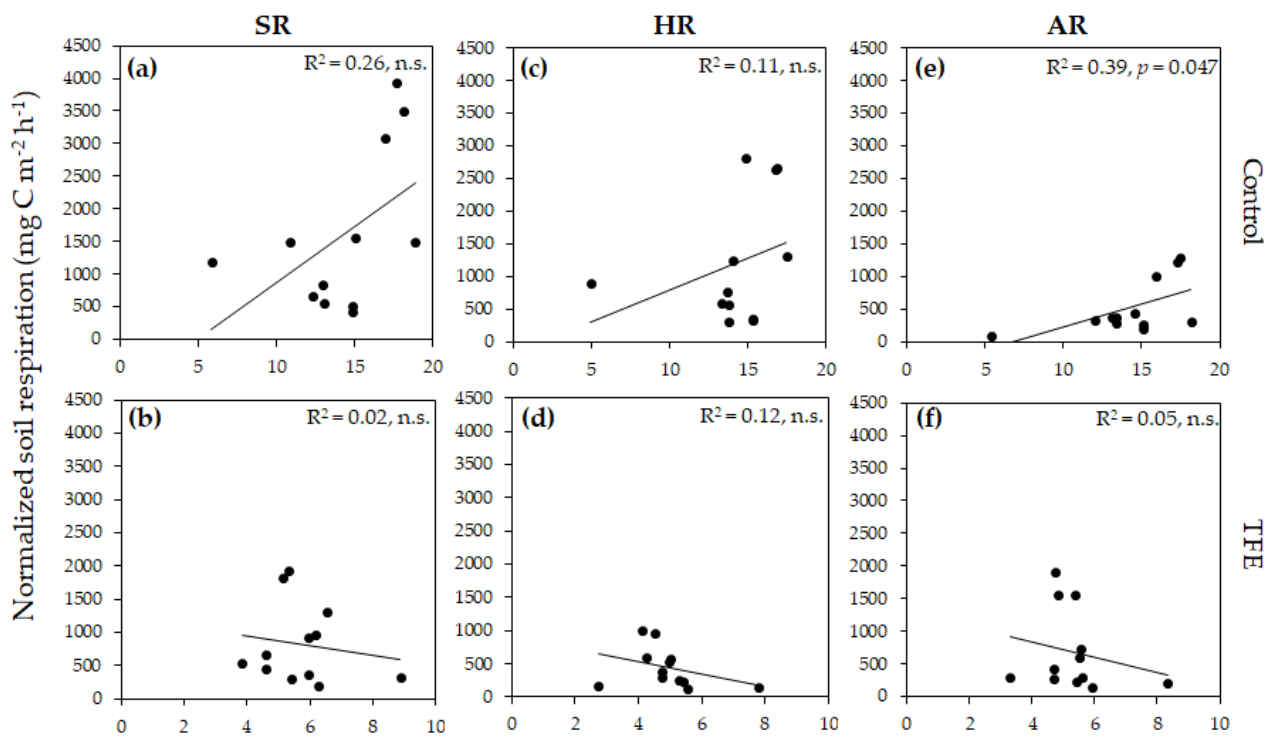

Soil water content (VWC, \%)

Figure 6. Soil water content dependency of soil respiration normalized to the mean daily soil temperature using $\mathrm{Q}_{10}$ values of $(\mathbf{a}, \mathbf{b})$ total soil respiration (SR), (c,d) heterotrophic soil respiration $(\mathrm{HR}),(\mathbf{e}, \mathbf{f})$ autotrophic soil respiration (AR) in control and throughfall exclusion (TFE) plots. $\mathrm{R}_{10}$ is the simulated soil respiration normalized to soil temperature at $10{ }^{\circ} \mathrm{C} . \mathrm{R}^{2}$ is coefficient of determination and $p$ represents $p$-value.

(a)
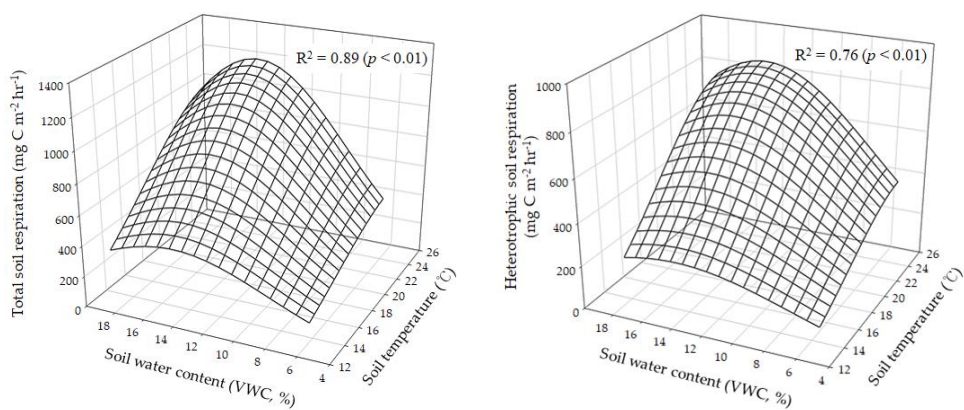

(b)
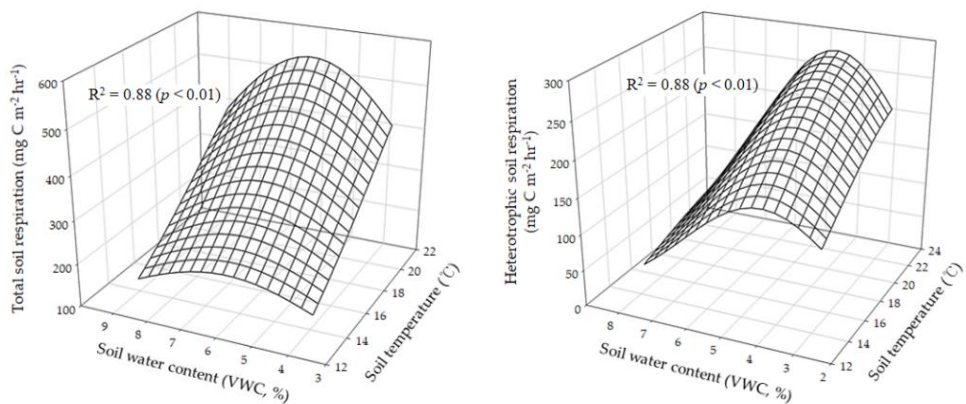

Figure 7. Combined effect of soil temperature and soil water content on the total soil respiration (SR) and heterotrophic soil respiration (HR) in (a) control plots and (b) TFE plots. $\mathrm{R}^{2}$ is coefficient of determination and $p$ represents $p$-value. 


\subsection{Effects of Drought on Soil Bacterial Community Diversity}

Table 5 presents the species diversity, evenness, and richness of the soil bacteria over the course of the TFE experiment. Species evenness (e) remained unchanged over the course of the TFE experiment in both control and TFE plots. In both 2016 and 2017, we found that the values for $\mathrm{H}^{\prime}$ and Chao1 were higher in the TFE plots than in the control plots. However, although in 2016, the ACE was $1.51 \%$ higher in the TFE plots than in the control plots, the value was 3.75\% lower in the TFE plots in 2017.

Table 5. Comparison between control and TFE plots with diversity, evenness, and richness of microbes over the TFE experiment. $\mathrm{H}^{\prime}$ = Shannon-Weaver Diversity Index values; e = species evenness; $\mathrm{ACE}=$ abundance-based coverage estimator index; Chao1 $=$ richness index.

\begin{tabular}{cccccccc}
\hline Year & Plot & $\mathbf{H}^{\prime}$ & e & ACE & Chao1 & ACE (\%) * & Chao1 (\%) * \\
\hline \multirow{2}{*}{2016} & Control & 6.57 & 0.75 & 130,024 & 3945 & & \\
& TFE & 6.77 & 0.77 & 131,987 & 6214 & +1.51 & +57.52 \\
2017 & Control & 6.59 & 0.75 & 121,975 & 3647 & & \\
& TFE & 6.81 & 0.77 & 117,396 & 5743 & -3.75 & +57.47 \\
\hline
\end{tabular}

$*+n$ and $-n$ indicate that the $n \%$ value is higher and lower, respectively, for the TFE plots compared with the control plots.

A total of 65 phyla were identified by the classifiable sequences. The dominant endemic members of soil bacterial community in the study site were Acidobacteria and Proteobacteria, followed by Chloroflexi, Actinobacteria, and Verrucomicrobia (Figure 8).

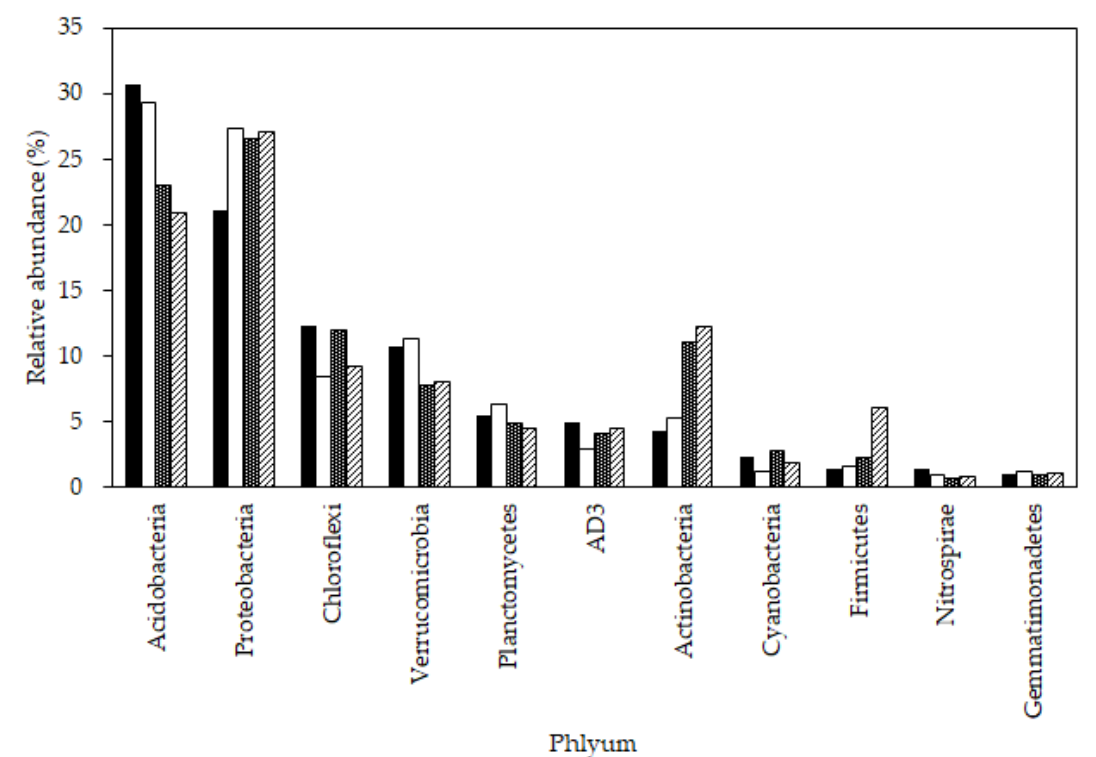

Control plot (August 2016)

口TFE plot (August 2016)

图Control plot (September 2017)

שTFE plot (September 2017)

Figure 8. Relative abundance of dominant bacterial phyla in the soil bacterial communities.

\subsection{Experimental Drought Impacts on Sapling Growth}

The average sapling diameters of the Korean pines were $2.6 \pm 0.2 \mathrm{~cm}, 3.3 \pm 0.2 \mathrm{~cm}$, and $4.0 \pm 0.2 \mathrm{~cm}$ in September 2016, May 2017, and October 2017, respectively, in the control plots $(n=15)$ and $2.3 \pm 0.2 \mathrm{~cm}, 2.9 \pm 0.2 \mathrm{~cm}$, and $3.1 \pm 0.3 \mathrm{~cm}$ in September 2016, May 2017, and October 2017, respectively, in the TFE plots $(n=19)$. During the TFE experiment, the mean sapling diameters of the Korean pines in the TFE plots were 11.5\%, 12.1\%, and 22.5\% smaller in September 2016, May 2017, and October 2017, respectively, compared with that of the control plots. Sapling growth showed significant differences between the control and TFE plots in October 2017 (Figure 9). 


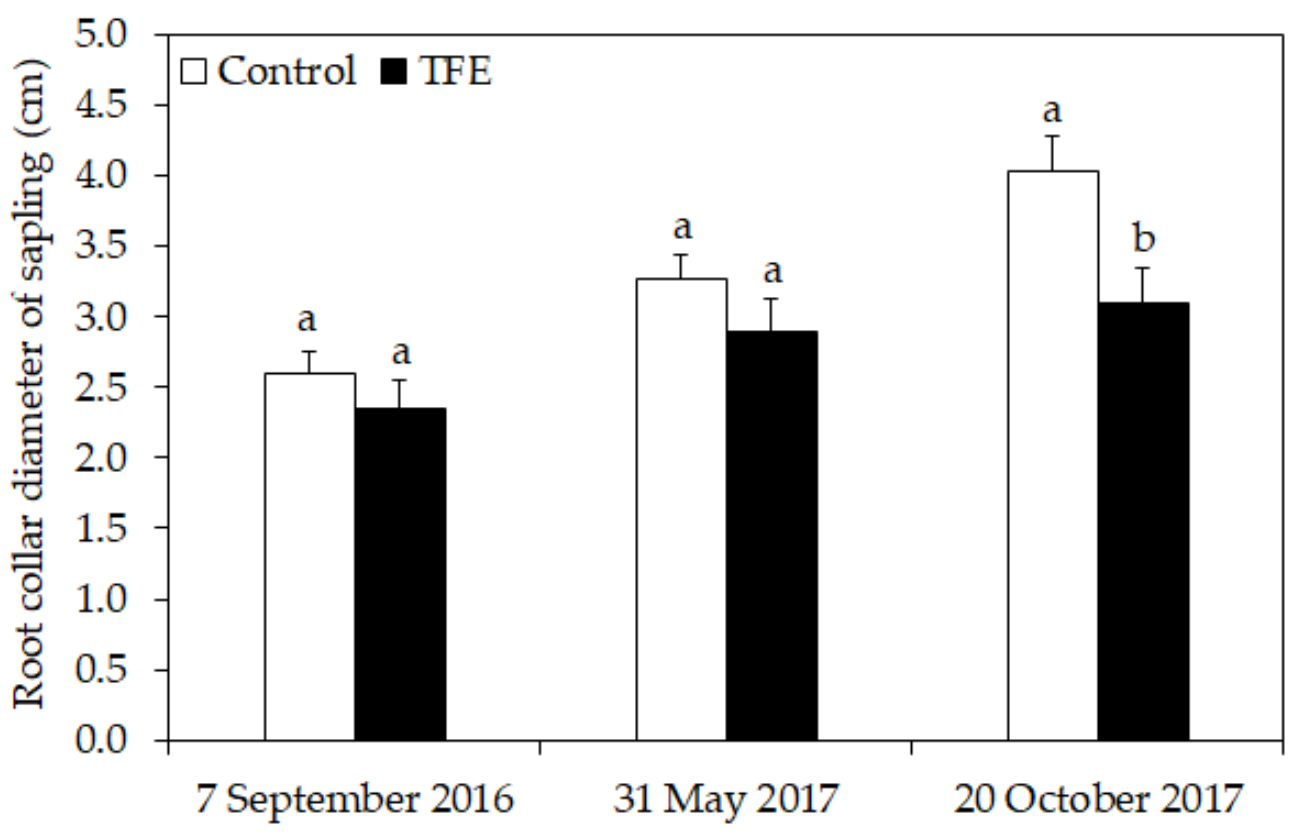

Figure 9. Root collar diameter increment of Korean pine saplings in the control and TFE plots with standard error (error bars). Different Latin letters indicate significantly different between control and TFE plots within each measuring day $(p<0.05)$. ( $n=15$ for control plots, $n=19$ for TFE plots).

\section{Discussion}

In the TFE experiment, the drought simulation resulted in no significant differences in soil temperatures between the control and TFE plots, although the soil water content was significantly lower in the TFE plots compared with that of the control plots. However, we cannot draw the conclusion that the TFE roof construction did not cause the greenhouse effect or decrement of PAR. The soil water content at both $10 \mathrm{~cm}$ and $30 \mathrm{~cm}$ soil depths decreased, but the reduction in soil water content at $30 \mathrm{~cm}$ was more moderate than that at $10 \mathrm{~cm}$ under drought conditions.

The soil $\mathrm{pH}, \mathrm{CEC}$, and concentrations of exchangeable cations were not notably different between the control and TFE plots during the TFE experiment. This may be because the soil organic matter content, which affects soil $\mathrm{pH}$ by releasing $\mathrm{H}^{+}$and is associated with changes in the cation exchange capacity, did not change during the experimental period [45-48]. Soil phosphate was lower than the optimal values for plant growth in the control and TFE plots both in 2016 and 2017, and soil nitrogen decreased in the TFE plots with simulated drought conditions over the course of the experiment. Given the decrease in HR of TFE plots, reduction of soil nitrogen might be due to inhibition of decomposition by soil bacteria under simulated drought conditions. In addition, reduction of influx of litterfall due to TFE roof also might affected soil nitrogen reduction. In terrestrial ecosystems, primary productivity is affected by nitrogen and phosphorous content [49-51]. In particular, nitrogen is the major nutrient for plant growth in temperate regions [52]. Therefore, the values of soil phosphate and nitrogen in the TFE plots might have affected tree growth during the experiment.

The soil $\mathrm{CO}_{2}$ efflux was unchanged shortly after the TFE experiment began due to the time required for the litter to dry out [53]. Therefore, in this study, the soil $\mathrm{CO}_{2}$ efflux was measured starting in April 2017, after a relatively severe dry season. SR was obviously inhibited in the TFE plots compared with that of the control plots. Muhr and Borken [31] have reported that TFE treatment results in a reduction of the matric potential in the organic layer and top mineral horizon so that soil respiration decreased. Decreases in soil respiration is in process with severe enough soil water stress after TFE [45]. In the present study, we found that the temperature sensitivity of soil respiration differed between $S R$ and its components. The $\mathrm{Q}_{10}$ value of 2.4 obtained for $\mathrm{SR}$ in control plots is similar to the reported global median of 2.4, whereas the value of 2.86 for SR in TFE plots is higher than the 
global mean value [8]. Our observation that the $Q_{10}$ values for $H R$ were higher than those obtained for AR indicates that the response of HR to temperature is more sensitive than that of AR. When soil water content is high, diffusion of oxygen may be hindered, so that decomposition and $\mathrm{CO}_{2}$ production may be inhibited [54]. In other words, soil respiration would be more sensitive to temperature during dry years than wet years [54]. In this study, soil respiration, especially HR, was measured during both the rainy and non-rainy seasons. The finding that the $Q_{10}$ values of $H R$ in the total study period were lower in the control plots than the TFE plots was may be due to the $\mathrm{Q}_{10}$ values of $H R$ in the rainy season. Furthermore, in contrast to $S R$ and $H R$, we found that the $Q_{10}$ values for AR decreased in the TFE plots compared with the control plots under simulated drought conditions.

However, although HR was significantly inhibited in TFE plots, AR was only approximately 1.37-fold lower in the TFE plots compared to that of the control plots. These results were consistent with those of Borken et al. [10], Wang et al. [23], and Muhr and Borken. [31] who reported that HR was more inhibited than AR under drought conditions. However, these results are contrary to those of other studies $[9,24,32]$. The observation that HR was reduced more than AR under drought conditions may be explained by several factors. Heterotrophic soil microbes seem to be more sensitive than roots and root-associated microbes under conditions of drought stress [31]. In addition, the activity of exoenzymes that decompose the soil organic matter is reduced as the soil becomes drier [18].

In the present study, we found that, with the exception ACE (abundance-based coverage estimator index), there was no apparent reduction in the indices' values for soil bacterial species richness under TFE conditions. Although in TFE plots we did detect a reduction in Chao1 (richness index) values in 2017 compared with those in 2016, a similar pattern was observed for control plots. Consequently, on the basis of the findings of this study, it is difficult to generalize regarding the responses of soil bacteria to drought conditions, which contrast with the findings of previous studies that have indicated that microbial abundance decreases in response to a lack of rainfall and warm soil conditions [55]. Nevertheless, given the notable reduction in HR in response to simulated drought conditions, it can be assumed that the activity of soil microbes is probably restricted under conditions of water stress [56,57].

The process of installing the chamber into the soil has been found to potentially cut off superficial roots, resulting in a lowering of AR [58]. However, in this study, the chamber was installed at a $1.4 \mathrm{~cm}$ soil depth, and thus it seems that these potential effects may not have been serious. AR was not significantly different between the control and TFE plots, which may have been due to the reduction in soil water content at $30 \mathrm{~cm}$ depth being relatively moderate under the simulated drought conditions. This is supported by the findings of Fisher et al. [59] who showed that drought conditions were not able to interrupt the flow of sap, which affects photosynthesis, in TFE plots. In addition, Salamanca et al. [60] showed that the litter mass of the TFE plots was not lower than that of the control plots even after a 12-month TFE experiment in a temperate forest. The lack of variability of AR under drought conditions may be further explained by a study showing that SR decreased approximately $30 \%$ while photosynthesis decreased by only $10 \%$ during an extremely dry summer [61].

It was clear that the growth of the Korean pine saplings based on diameter measurements in the TFE plots decreased during the experiment. The soil properties at the beginning of the experiment were not optimal for vegetation growth in this site, and the relative reduction in soil nitrogen may have affected tree growth in the TFE plots. However, AR reduction in the TFE plots compared to the control plots was lower than that of SR and HR, presumably due to a reduction in sapling growth caused by not only simulated drought but also the greenhouse effect or decrement of PAR under the roof. On the other hand, a lag between the beginning of the TFE experiment and a significant reduction in tree growth was observed.

A linear regression model between soil water content and normalized soil respiration was significant for the only normalized AR in the control plots. This result was consistent with studies that have found a linear relationship between soil respiration and water content, which is not generally observed [62,63]. With respect to TFE plots, given that soil water content was restricted artificially, such that the range of soil water contents was small, it is more difficult to explain the responses of soil 
respiration to soil water content under TFE conditions. Davidson et al. [54], and Lee and Mun. [64] reported that soil respiration was strongly affected by soil temperature. In addition, Sheik et al. [55] reported that soil respiration was related to the decomposition activity of microbes, which increases as soil temperatures increase under normal rainfall conditions. The responses of soil respiration to soil temperature were more notable in the control plots than in the TFE plots. This result agrees with previous studies that have shown that soil respiration was insensitive to temperature changes when soil water content was low [65].

The nonlinear relationship was detected between SR, HR, and soil temperature and soil water content both in the control and TFE plots. The coefficient of determination between SR, HR, and soil temperature, and soil water content was higher for the multiple nonlinear regression compared to that of the single linear regression. The regression model indicated that soil respiration increased as soil temperature and water content increased, although soil respiration decreased when the soil water content was high. Moreover, the soil water content that caused a reduction in soil respiration was higher in the control plots than in the TFE plots. Suseela et al. [66] reported that when soil water content was recorded either below $15 \%$ or above $26 \%$, HR decreased. Furthermore, Davidson et al. [54] reported a similar result, with soil respiration decreasing when extreme drought occurred during the rainy season. The authors also found that soil respiration was strongly yet inconsistently influenced by soil temperature, while the variation of soil respiration was better explained by the combined effects of soil temperature and other factors, such as soil moisture. Our result agreed with those reports. The multiple nonlinear regression model was not appropriate for describing the relationship between AR and soil temperature and water content because the fitted parameters for the regression model did not converge. This result is similar to the report that there is no single universal model that predicts soil $\mathrm{CO}_{2}$ flux based on soil temperature or water content [67].

\section{Conclusions}

In response to simulated drought conditions, the growth of Korean pine saplings; abundance-based coverage estimator index; and total SR, HR, and AR in TFE plots were lower than those in the control plots. The decreases in the growth of Korean pine saplings, total SR, and AR were significant. However, due to the greenhouse effect of the roof, we cannot draw the conclusion that the reduction in AR and sapling growth are the only effects of drought simulation. The changes in HR and AR in the TFE experiment varied remarkably, although HR showed more sensitivity to drought conditions.

In contrast to soil temperature, soil water content, as a single independent variable, was unable to explain the observed effects of TFP on soil respiration. Furthermore, the responses of soil respiration to soil temperature vary with soil moisture conditions, and consequently, the combined effects of soil temperature and water content was better able to explain the variability in SR and HR than the independent effects of either soil temperature or water content. However, we could not fit the AR in the control and TFE plots to the multiple nonlinear regression. Although we detected no reduction in the temperature sensitivity of HR under drought conditions, we did find that HR is more restricted and sensitive to temperature under drought conditions than AR.

It is necessary to quantify the responses of SR and its components under various drought intensity conditions in diverse forest ecosystems for long-term monitoring experiments. Furthermore, when predicting the responses of soil $\mathrm{CO}_{2}$ efflux in a forest ecosystem to drought conditions, it is necessary to consider the asymmetric responses of HR and AR.

Author Contributions: Conceptualization, H.M.C. and B.C.; Data curation, I.K.; Formal analysis, I.K.; Funding acquisition, B.C.; Investigation, B.C.; Methodology, B.C.; Project administration, B.C.; Resources, B.C.; Software, B.C.; Supervision, H.M.C. and B.C.; Validation, H.M.C. and B.C.; Visualization, I.K.; Writing-original draft, I.K.; Writing-review and editing, H.M.C. and B.C. All authors have read and agreed to the published version of the manuscript.

Funding: This research was supported by Basic Science Research Program through the National Research Foundation of Korea (NRF) funded by the Korea government (MSIP) (No. 2015R1C1A1A01052341) and the Ministry of Education (NRF-2018R1D1A1B07041766). Also, this study was carried out with the support of 'R\&D 
Program for Forest Science Technology (2019151C10-2023-0301)' provided by Korea Forest Service (Korea Forestry Promotion Institute).

Acknowledgments: We thank the editor and two anonymous reviewers who provided constructive comments on our manuscript.

Conflicts of Interest: The authors declare no conflict of interest.

\section{References}

1. IPCC. Climate Change 2014: Synthesis Report; Contribution of Working Groups I, II and III to the Fifth Assessment Report of the Intergovernmental Panel on Climate Change; Core Writing Team, Pachauri, R., Meyer, L., Eds.; IPCC: Geneva, Switzerland, 2014.

2. Bond-Lamberty, B.; Thomson, A. Temperature-associated increases in the global soil respiration record. Nature 2010, 464, 579-582. [CrossRef] [PubMed]

3. Lellei-Kovács, E.; Botta-Dukát, Z.; Dato, G.d.; Estiarte, M.; Guidolotti, G.; Kopittke, G.R.; Kovács-Láng, E.; Kröel-Dulay, G.; Larsen, K.S.; Peñuelas, J. Temperature dependence of soil respiration modulated by thresholds in soil water availability across European shrubland ecosystems. Ecosystems 2016, 19, 1-18. [CrossRef]

4. $\quad$ Eom, J.Y.; Jeong, S.H.; Chun, J.H.; Lee, J.H.; Lee, J.S. Long-term characteristics of soil respiration in a Korean cool-temperate deciduous forest in a monsoon climate. Anim. Cells. Syst. 2018, 22, 100-108. [CrossRef]

5. Jeong, S.H.; Eom, J.Y.; Park, J.Y.; Lee, J.H.; Lee, J.S. Characteristics of accumulated soil carbon and soil respiration in temperate deciduous forest and alpine pastureland. J. Ecol. Environ. 2018, 42, 3. [CrossRef]

6. Dixon, R.K.; Solomon, A.M.; Brown, S.; Houghton, R.A.; Trexier, M.C.; Wisniewski, J. Carbon pools and flux of global forest ecosystems. Science 1994, 263, 185-190. [CrossRef] [PubMed]

7. Jiang, H.; Deng, Q.; Zhou, G.; Hui, D.; Zhang, D.; Liu, S.; Chu, G.; Li, J. Responses of soil respiration and its temperature/moisture sensitivity to precipitation in three subtropical forests in southern China. Biogeosciences 2013, 10, 3963-3982. [CrossRef]

8. Raich, J.W.; Schlesinger, W.H. The global carbon dioxide flux in soil respiration and its relationship to vegetation and climate. Tellus B 1992, 44, 81-99. [CrossRef]

9. Hinko-Najera, N.; Fest, B.; Livesley, S.J.; Arndt, S. Reduced throughfall decreases autotrophic respiration: But not heterotrophic respiration in a dry temperate broadleaved evergreen forest. Agric. For. Meteorol. 2015, 200, 66-77. [CrossRef]

10. ArchMiller, A.A.; Samuelson, L.J. Intra-annual variation of soil respiration across four heterogeneous longleaf pine forests in the southeastern United States. For. Ecol. Manag. 2016, 359, 370-380. [CrossRef]

11. Noh, N.J.; Kuribayashi, M.; Saitoh, T.M.; Nakaji, T.; Nakamura, M.; Hiura, T.; Muraoka, H. Responses of soil, heterotrophic, and autotrophic respiration to experimental open-field soil warming in a cool-temperate deciduous forest. Ecosystems 2015, 19, 504-520. [CrossRef]

12. Xu, X.; Shi, Z.; Li, D.; Zhou, X.; Sherry, R.A.; Luo, Y. Plant community structure regulates responses of prairie soil respiration to decadal experimental warming. Glob. Chang. Biol. 2015, 21, 3846-3853. [CrossRef] [PubMed]

13. Borken, W.; Savage, K.; Davidson, E.A.; Trumbore, S.E. Effects of experimental drought on soil respiration and radiocarbon efflux from a temperate forest soil. Glob. Chang. Biol. 2006, 12, 177-193. [CrossRef]

14. Sotta, E.D.; Veldkamp, E.; Schwendenmann, L.; Guimarães, B.R.; Paixão, R.K.; Ruivo, M.D.L.P.; Lola da Costa, A.C.; Meir, P. Effects of an induced drought on soil carbon dioxide $\left(\mathrm{CO}_{2}\right)$ efflux and soil $\mathrm{CO}_{2}$ production in an Eastern Amazonian rainforest, Brazil. Glob. Chang. Biol. 2007, 13, 2218-2229. [CrossRef]

15. Cleveland, C.C.; Wieder, W.R.; Reed, S.C.; Townsend, A.R. Experimental drought in a tropical rain forest increases soil carbon dioxide losses to the atmosphere. Ecology 2010, 91, 2313-2323. [CrossRef] [PubMed]

16. van Straaten, O.; Veldkamp, E.; Corre, M.D. Simulated drought reduces soil $\mathrm{CO}_{2}$ efflux and production in a tropical forest in Sulawesi, Indonesia. Ecosphere 2011, 2, 1-22. [CrossRef]

17. Doughty, C.E.; Metcalfe, D.B.; Girardin, C.A.; Amezquita, F.F.; Cabrera, D.G.; Huasco, W.H.; Silva-Espejo, J.E.; Araujo-Murakami, A.; da Costa, M.C.; Rocha, W.; et al. Drought impact on forest carbon dynamics and fluxes in Amazonia. Nature 2015, 519, 78-82. [CrossRef] 
18. Suseela, V.; Dukes, J.S. The responses of soil and rhizosphere respiration to simulated climatic changes vary by season. Ecology 2013, 94, 403-413. [CrossRef]

19. Zhang, X.; Zhang, Y.; Sha, L.; Wu, C.; Tan, Z.; Song, Q.; Liu, Y.; Dong, L. Effects of continuous drought stress on soil respiration in a tropical rainforest in southwest China. Plant Soil 2015, 394, 343-353. [CrossRef]

20. Hanson, P.J.; Edwards, N.T.; Garten, C.T.; Andrews, J.A. Separating root and soil microbial contributions to soil respiration: A review of methods and observations. Biogeochemistry 2000, 48, 115-146. [CrossRef]

21. Janssens, I.A.; Crookshanks, M.; Taylor, G.; Ceulemans, R. Elevated atmospheric $\mathrm{CO}_{2}$ increases fine root production, respiration, rhizosphere respiration and soil $\mathrm{CO}_{2}$ efflux in Scots pine seedlings. Glob. Chang. Biol. 1998, 4, 871-878. [CrossRef]

22. Bardgett, R.D.; Freeman, C.; Ostle, N.J. Microbial contributions to climate change through carbon cycle feedbacks. ISME J. 2008, 2, 805-814. [CrossRef] [PubMed]

23. Wang, Y.; Hao, Y.; Cui, X.Y.; Zhao, H.; Xu, C.; Zhou, X.; Xu, Z. Responses of soil respiration and its components to drought stress. J. Soils Sediments 2014, 14, 99-109. [CrossRef]

24. Huang, S.; Ye, G.; Lin, J.; Chen, K.; Xu, X.; Ruan, H.; Tan, F.; Chen Han, Y.H. Autotrophic and heterotrophic soil respiration responds asymmetrically to drought in a subtropical forest in the Southeast China. Soil Biol. Biochem. 2018, 123, 242-249. [CrossRef]

25. Jing, Y.; Wang, Y.; Liu, S.; Zhang, X.; Wang, Q.; Liu, K.; Yin, Y.; Deng, J. Interactive effects of soil warming, throughfall reduction, and root exclusion on soil microbial community and residues in warm-temperate oak forests. Appl. Soil Ecol. 2019, 142, 52-58. [CrossRef]

26. Wan, S.; Norby, R.J.; Ledford, J.; Weltzin, J.F. Responses of soil respiration to elevated $\mathrm{CO}_{2}$, air warming, and changing soil water availability in a model old-field grassland. Glob. Chang. Biol. 2007, 13, 2411-2424. [CrossRef]

27. Selsted, M.B.; van der Linden, L.; Ibrom, A.; Michelsen, A.; Larsen, K.S.; Pedersen, J.K.; Mikkelsen, T.N.; Pilegaard, K.; Beier, C.; Ambus, P. Soil respiration is stimulated by elevated $\mathrm{CO}_{2}$ and reduced by summer drought: Three years of measurements in a multifactor ecosystem manipulation experiment in a temperate heathland (CLIMAITE). Glob. Chang. Biol. 2012, 18, 1216-1230. [CrossRef]

28. Brüggemann, N.; Gessler, A.; Kayler, Z.E.; Keel, S.; Badeck, F.W.; Barthel, M.; Boeckx, P.; Buchmann, N.; Brugnoli, E.; Esperschütz, J.; et al. Carbon allocation and carbon isotope fluxes in the plant-soil-atmosphere continuum: A review. Biogeosciences 2011, 8, 3457-3489. [CrossRef]

29. Hopkins, F.; Gonzales-Meler, M.A.; Flower, C.E.; Lynch, D.J.; Czimczik, C.; Tang, J.; Subke, J.A. Ecosystem-level controls on root-rhizosphere respiration. New Phytol. 2013, 199, 339-351. [CrossRef]

30. Yahdjian, L.; Sala, O.E. A rainout shelter design for intercepting different amounts of rainfall. Oecologia 2002, 133, 95-101. [CrossRef]

31. Muhr, J.; Borken, W. Delayed recovery of soil respiration after wetting of dry soil further reduces $C$ losses from a Norway spruce forest soil. J. Geophys. Res. 2009, 114, 1088. [CrossRef]

32. Kopittke, G.R.; Tietema, A.; van Loon, E.E.; Asscheman, D. Fourteen annually repeated droughts suppressed autotrophic soil respiration and resulted in an ecosystem change. Ecosystems 2014, 17, 242-257. [CrossRef]

33. Schlesinger, W.H. Carbon balance in terrestrial detritus. Annu. Rev. Ecol. Syst. 1977, 8, 51-81. [CrossRef]

34. Singh, J.S.; Gupta, S.R. Plant decomposition and soil respiration in terrestrial ecosystems. Bot. Rev. 1977, 43, 449-528. [CrossRef]

35. Raich, J.W.; Tufekcioglu, A. Vegetation and soil respiration: Correlations and controls. Biogeochemistry 2000, 48, 71-90. [CrossRef]

36. Grace, J.; Berninger, F.; Nagy, L. Impacts of Climate Change on the Tree Line. Ann. Bot. 2002, 90, 537-544. [CrossRef]

37. Kang, S.; Doh, S.; Lee, D.; Lee, D.; Jin, V.L.; Kimball, J.S. Topographic and climatic controls on soil respiration in six temperate mixed-hardwood forest slopes, Korea. Glob. Chang. Biol. 2003, 9, 1427-1437. [CrossRef]

38. Lee, E.H.; Lim, J.H.; Lee, J.S. A Review on Soil Respiration Measurement and Its Application in Korea. Korean J. Agric. For. Meteorol. 2010, 12, 262-276. (In Korean with English abstract)

39. Lee, M.S.; Nakane, K.; Nakatsubo, T.; Koizumi, H. Seasonal changes in the contribution of root respiration to total soil respiration in a cool-temperate deciduous forest. Plant Soil 2003, 255, 311-318. [CrossRef]

40. Petritan, A.M.; Von Lüpke, B.; Petritan, I.C. Effects of shade on growth and mortality of maple (Acer pseudoplatanus), ash (Fraxinus excelsior) and beech (Fagus sylvatica) saplings. Forestry 2007, 80, 397-412. [CrossRef] 
41. Rochette, P.; Ellert, B.; Gregorich, E.G.; Desjardins, R.L.; Pattey, E.; Lessard, R.; Johnson, B.G. Description of a dynamic closed chamber for measuring soil respiration and its comparison with other techniques. Can. J. Soil Sci. 1997, 77, 195-203. [CrossRef]

42. Shannon, C.E.; Weaver, W. The Mathematical Theory of Communication. Bell Syst. Tech. J. 1949, $27,379-423$. [CrossRef]

43. Pielou, E.C. The measurement of diversity in different types of biological collections. J. Theor. Biol. 1966, 13, 131-144. [CrossRef]

44. National Institute of Forest Science. Evaluation Report of Forest Health Vitality; National Institute of Forest Science: Seoul, Korea, 2016; p. 77. (In Korean)

45. Williams, C.H. Soil acidification under clover pasture. Aust. J. Exp. Agric. 1980, 64, 561-567. [CrossRef]

46. Helyar, K.R.; Porter, W.M. Soil acidification, its measurement and the processes involved. In Soil Acidity and Plant Growth; Robson, A.D., Ed.; Academic Press Australia: Sydney, Australia, 1989; pp. 61-101.

47. Shaw, P.A.; Bryant, R.G. Playas, pans and salt lakes. In Arid Zone Geomorphology: Process, Form and Change in Drylands; Thomas, D.S.G., Ed.; John Wiley \& Sons, Ltd.: Chichester, UK, 2011; pp. 373-401.

48. Bolan, N.S.; Hedley, M.J.; White, R.E. Processes of soil acidification during nitrogen cycling with emphasis on legume based pastures. Plant Soil 1991, 134, 53-63. [CrossRef]

49. Tang, C.; Yu, Q. Impact of chemical composition of legume residues and initial soil $\mathrm{pH}$ on $\mathrm{pH}$ change of a soil after residue incorporation. Plant Soil 1999, 215, 29-38. [CrossRef]

50. Chapin, F.S., III. The mineral nutrition of wild plants. Annu. Rev. Ecol. Syst. 1980, 11, 233-260. [CrossRef]

51. Aerts, R.; Chapin, F.S., III. The mineral nutrition of wild plants revisited: A re-evaluation of processes and patterns. Adv. Ecol. Res. 1999, 30,1-67.

52. Elser, J.J.; Bracken, M.E.S.; Cleland, E.E.; Gruner, D.S.; Harpole, W.S.; Hillebrand, H.; Ngai, J.T.; Seabloom, E.W.; Shurin, J.B.; Smith, J.E. Global analysis of nitrogen and phosphorus limitation of primary producers in freshwater, marine and terrestrial ecosystems. Ecol. Lett. 2007, 10, 1135-1142. [CrossRef]

53. Reich, P.B.; Oleksyn, J. Global patterns of plant leaf N and P in relation to temperature and latitude. Proc. Natl. Acad. Sci. USA 2004, 101, 11001-11006. [CrossRef]

54. Davidson, E.A.; Belk, E.; Boon, R.D. Soil water content and temperature as independent or confounded factors controlling soil respiration in a temperature mixed hardwood forest. Glob. Chang. Biol. 1998, 4, 217-227. [CrossRef]

55. Sheik, C.S.; Beasley, W.H.; Elshahed, M.S.; Zhou, X.; Luo, Y.; Krumholz, L.R. Effect of warming and drought on grassland microbial communities. ISME J. 2011, 5, 1692-1700. [CrossRef] [PubMed]

56. Lavine, M.B.; Foster, R.J.; Goodine, G. Seasonal and annual changes in soil respiration in relation to soil temperature, water potential and trenching. Tree Physiol. 2004, 24, 415-424. [CrossRef] [PubMed]

57. Li, Y.Q.; Xu, M.; Zou, X.M.; Xia, Y. Soil $\mathrm{CO}_{2}$ efflux and fungal and bacterial biomass in a plantation and a secondary forest in wet tropics in Puerto Rico. Plant Soil 2005, 268, 151-160. [CrossRef]

58. Wang, W.J.; Zu, Y.G.; Wang, H.M.; Hirano, T.; Takagi, K.; Sasa, K.; Koike, T. Effect of collar insertion on soil respiration in a larch forest measured with a LI-6400 soil $\mathrm{CO}_{2}$ flux system. J. For. Res. 2005, 10, 57-60. [CrossRef]

59. Fisher, R.A.; Williams, M.; Lola da Costa, A.; Malhi, Y.; Costa, R.F.; Almeida, S.; Meir, P. The response of an Eastern Amazonian rain forest to drought stress: Results and modelling analyses from a through-fall exclusion experiment. Glob. Chang. Biol. 2007, 13, 2361-2378. [CrossRef]

60. Salamanca, E.F.; Kaneko, N.; Katagiri, S. Rainfall manipulation effects on litter decomposition and the microbial biomass of the forest floor. Appl. Soil. Ecol. 2003, 22, 271-281. [CrossRef]

61. Goulden, M.L.; Munger, J.M.; Fan, S.M.; Daube, B.C.; Wofsy, S.C. Exchange of carbon dioxide by a deciduous forest: Response to interannual climate variability. Science 1996, 271, 1576-1578. [CrossRef]

62. Cook, F.J.; Orchard, V.A. Relationships between soil respiration and soil moisture. Soil Biol. Biochem. 2008, 40, 1013-1018. [CrossRef]

63. Miao, Y.; Hongyan, H.; Yue, D.; Qian, Z.; Lin, J.; Dafeng, H.; Shiqiang, W. Nonlinear responses of soil respiration to precipitation changes in a semiarid temperate steppe. Sci. Rep. 2017, 7, 45782. [CrossRef]

64. Lee, Y.Y.; Mun, H.T. A study on the soil respiration in a Quercus acutissima forest. J. Ecol. Field. Biol. 2001, 24, 141-147. 
65. Yuste, J.C.; Janssens, I.A.; Carrara, A.; Meiresonne, L.; Ceulemans, R. Interactive effects of temperature and precipitation on soil respiration in a temperate maritime pine forest. Tree Physiol. 2003, 23, 1263-1270. [CrossRef] [PubMed]

66. Suseela, V.; Conant, R.T.; Wallenstein, M.D.; Dukes, J.S. Effects of soil moisture on the temperature sensitivity of heterotrophic respiration vary seasonally in an old-field climate change experiment. Glob. Chang. Biol. 2012, 18, 336-348. [CrossRef]

67. Jia, B.; Zhou, G.; Wang, Y.; Wang, F.; Wang, X. Effects of temperature and soil water-content on soil respiration of grazed and ungrazed Leymus chinensis steppes, Inner Mongolia. J. Arid. Environ. 2006, 67, 60-76. [CrossRef]

(c)

(C) 2020 by the authors. Licensee MDPI, Basel, Switzerland. This article is an open access article distributed under the terms and conditions of the Creative Commons Attribution (CC BY) license (http://creativecommons.org/licenses/by/4.0/). 